\title{
The History of the Glasgow School of Art Fashion Show an Evolving Pedagogy
}

Helena Britt ${ }^{\mathrm{a} *}$, Susannah Waters ${ }^{\mathrm{b}}$ and Jimmy Stephen-Cran ${ }^{\mathrm{c}}$

${ }^{a}$ Department Fashion \& Textiles, Glasgow School of Art, Glasgow, United Kingdom; ${ }^{b}$ Archives and Collections, Glasgow School of Art, Glasgow, United Kingdom;

${ }^{b}$ Department of Fashion \& Textiles, Glasgow School of Art, Glasgow, United Kingdom 167 Renfrew Street, Glasgow, G3 6RF;

h.britt@gsa.ac.uk 


\section{The History of the Glasgow School of Art Fashion Show an Evolving Pedagogy}

This article discusses a research project which utilized archive sources to construct the history of an art school fashion show, to examine the event as higher education (HE) learning and teaching method. The study of textiles has been part of the activities of the Glasgow School of Art (GSA) since its inception. Fashion as a discipline resulting in a distinct qualification is relatively new to the School. However, GSA's fashion show began in 1947 and this article focuses on a study undertaken to celebrate the seventieth-anniversary of the event. The collaborative project involved staff from GSA's Department of Fashion \& Textiles, Archives \& Collections (A\&C) and Alumni Relations. The GSA archive was essential to the inquiry as it contains a wealth of information relating to the history of the School, its staff and students. The project methodology combined archival investigation, documentary and visual analysis, and participant feedback, towards exhibition curation. Outcomes from the project included an exhibition which ran alongside the 2017 student fashion shows and accompanying student-led events. This article provides insight into the types of archival material utilized and discusses the historical development of the show focusing on its evolving role in learning and teaching. The concluding section proposes areas for further investigation and highlights issues for consideration by collectors, institutions and archives.

Keywords: fashion show, art school, textile design, fashion design; archives; learning and teaching

\section{Introduction}

The Glasgow School of Art (GSA) was established in 1845, as a branch of the Government School of Design. Subjects related to or involving the study of textiles have been part of the School's activities since its formation. The collecting of textile artifacts for learning and teaching purposes is believed to have commenced in 1894 with the establishment of the Embroidery Department (Arthur 2005). Relating specifically to fashion, in 1907 a minor course was available in illustration, later replaced by minor courses in fashion plate drawing, costume and fashion drawing. During the 1930s, 
costume and fashion design ran as a minor course. However, as an area of study resulting in distinct qualification, fashion only entered GSA's portfolio of programmes at postgraduate level in 2004 and undergraduate level in 2010.

Despite the absence of fashion as a specific programme, GSA's fashion show has been in existence since 1947. Today, GSA's BA (Hons) Textile Design and BA (Hons) Fashion Design programmes comprise four years full-time study (with entry into first, second or third year possible). The seventieth-anniversary project aimed to develop understanding surrounding the GSA fashion show by identifying relevant material held by GSA's Archives and Collections (A\&C) and other resources; locate and accession relevant artefacts and insights from GSA alumni; construct a history of the event; curate an exhibition about the event; examine the fashion show as pedagogical approach; and establish areas for further investigation from studying this local event

\section{GSA Fashion Show Archives}

GSA's archives contain various types of records which include information about the School's fashion shows such as news cuttings, photographs, prospectuses, annual reports, documents, ephemera and audio-visual recordings. News cuttings are either compiled in bound volumes (1864-1968) or loose in folders (1960s-2000s) and contain extracts from local and national newspapers. The bound volumes are fragile and therefore access to this material is heavily restricted. Often articles have been cut from newspapers with authors and page numbers unknown.

Within the School's collection of loose photographs, often taken for the School's prospectus, approximately 30 photographs relate to the fashion show (dating from 19521995). There are also two albums from the 1952 and 1953 fashion shows which depict 
backstage activity, student advertising, staging and models wearing student-made garments. These high-quality photographs (currently licenced by Getty Images) are believed to have been documented for Picture Post magazine. Prospectuses include photographs from 1964/65 onwards and the fashion show is first featured in this edition. Some of the institutions annual reports briefly mention the fashion show (c1955-78). During the project, it was not possible to view the equivalent documents from 1980 onwards due to access restrictions. A small folder of papers from c1950-60 was considered as it contained letters related to the event. Within the archive, fashion show ephemera includes programmes, flyers, tickets and posters. Audio-visual recordings exist of the 1978, 1982, 1984, 1985 and 1986 fashion shows, providing insight into staging, models on stage, choreography, music and in some cases backstage footage, and the audience.

Publications by Ferguson (1995) and Arthur (2005) provide insights into the history of GSA and the collecting and teaching of textiles at the School. Arthur's (1989) book about Kathleen Whyte describes teaching and learning in Embroidered and Woven Textiles at GSA, between 1948-1974. Work by the same author on the influential designer and educator, 'Robert Stewart design, 1946-95' mentions the GSA fashion show related to the Printed Textiles Department (Arthur 2003). Podcasts by Banerjee (2015) resulting from a study of GSA's School of Fine Art pedagogy from 1970-1986, capture some relevant insights from former staff and students. Within the GSA Library, Fraser's (1991) unpublished student dissertation provides the most comprehensive account of the GSA fashion show prior to the seventieth-anniversary project. In addition to these materials, GSA's Department of Fashion \& Textiles holds a small collection of items from more recent fashion shows (2000-onwards), including news cuttings, 
magazine features, photographs, posters, programmes, documentation and other ephemera. The School's Flickr (GSA 2008) pages, various websites, blogs, Youtube, Vimeo recordings, Instagram, Twitter and Facebook feeds also provide visual content from more recent GSA fashion shows (2009-onwards). Online postings have been created by students organizing the event and GSA staff, others by visitors, photographers or film crew documenting the show.

\section{GSA Alumni Participants}

Within the existing A\&C records described there are gaps for certain time periods. Also, before the project, garments included in past fashion shows were not part of the School's archives. In 2016, to extend beyond the existing fashion show archive resources, staff from GSA's A\&C, Department of Fashion \& Textiles and Alumni Relations formed a callout to alumni for memories of the event and related materials. From the initial request, 45 responses were received and approximately $25 \%$ have resulted in items being deposited or scanned by A\&C. Despite the appeal for responses by the end of September 2016, to enable researchers working on the project to use the material in an exhibition, items continued to be sent to the School. Also, the Fashion Show 70 $0^{\text {th }}$ Anniversary Exhibition (Britt et al. 2017a) elicited responses beyond the initial callout and follow-up work such as accessioning artifacts and oral history interviews continue. The exhibition (Figure 1), resulting from the project, provided a visual historiography of the fashion show through displays of photographs, ephemera, news cuttings and films (Figure 2). The private view for the exhibition offered an opportunity for data collection with researchers on hand to record further insights provided by GSA alumni and those involved with the event over the years. 


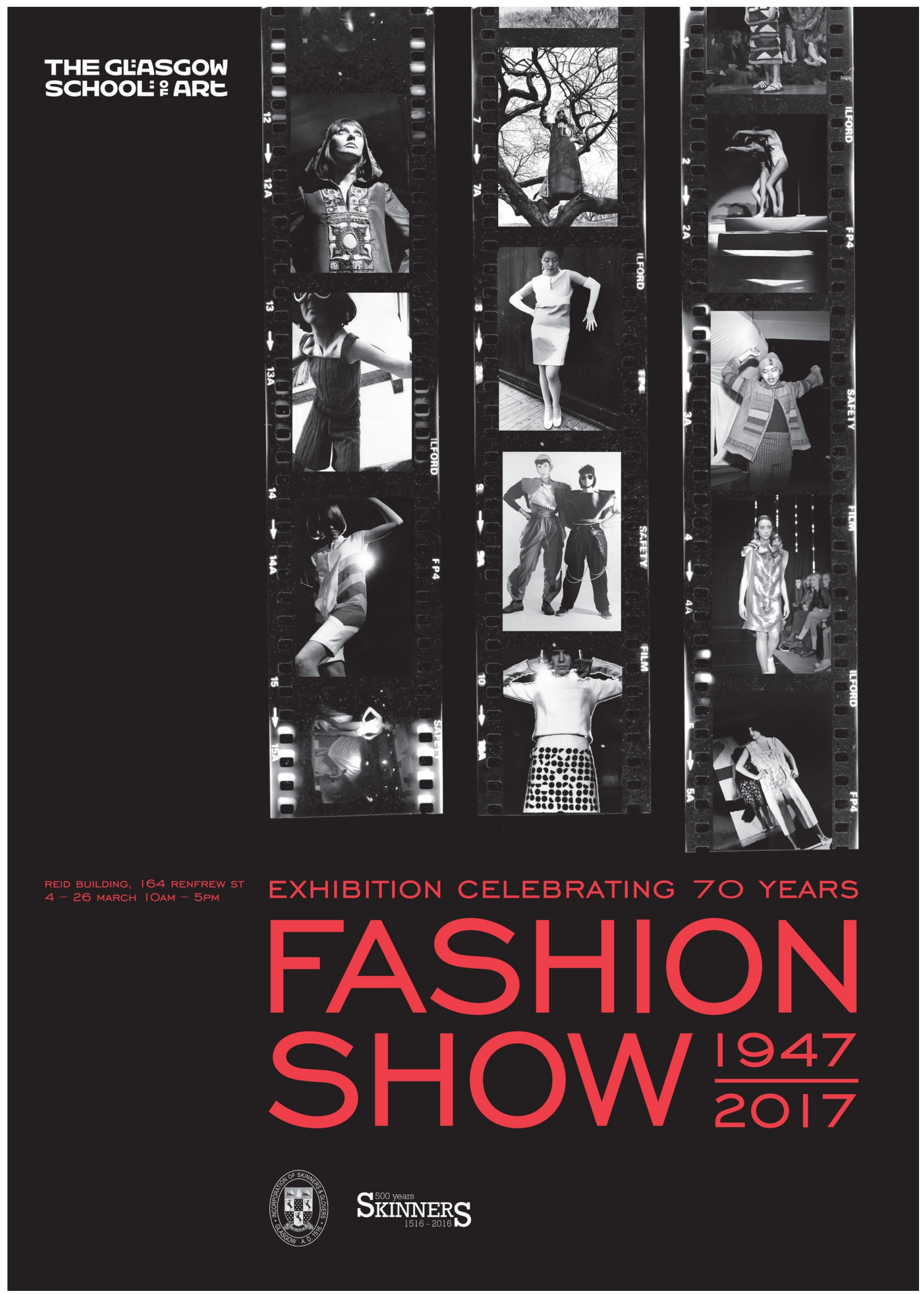

Figure 1. GSA Fashion Show $70^{\text {th }}$ Anniversary Exhibition poster, designed by Maeve Redmond, 2017. 


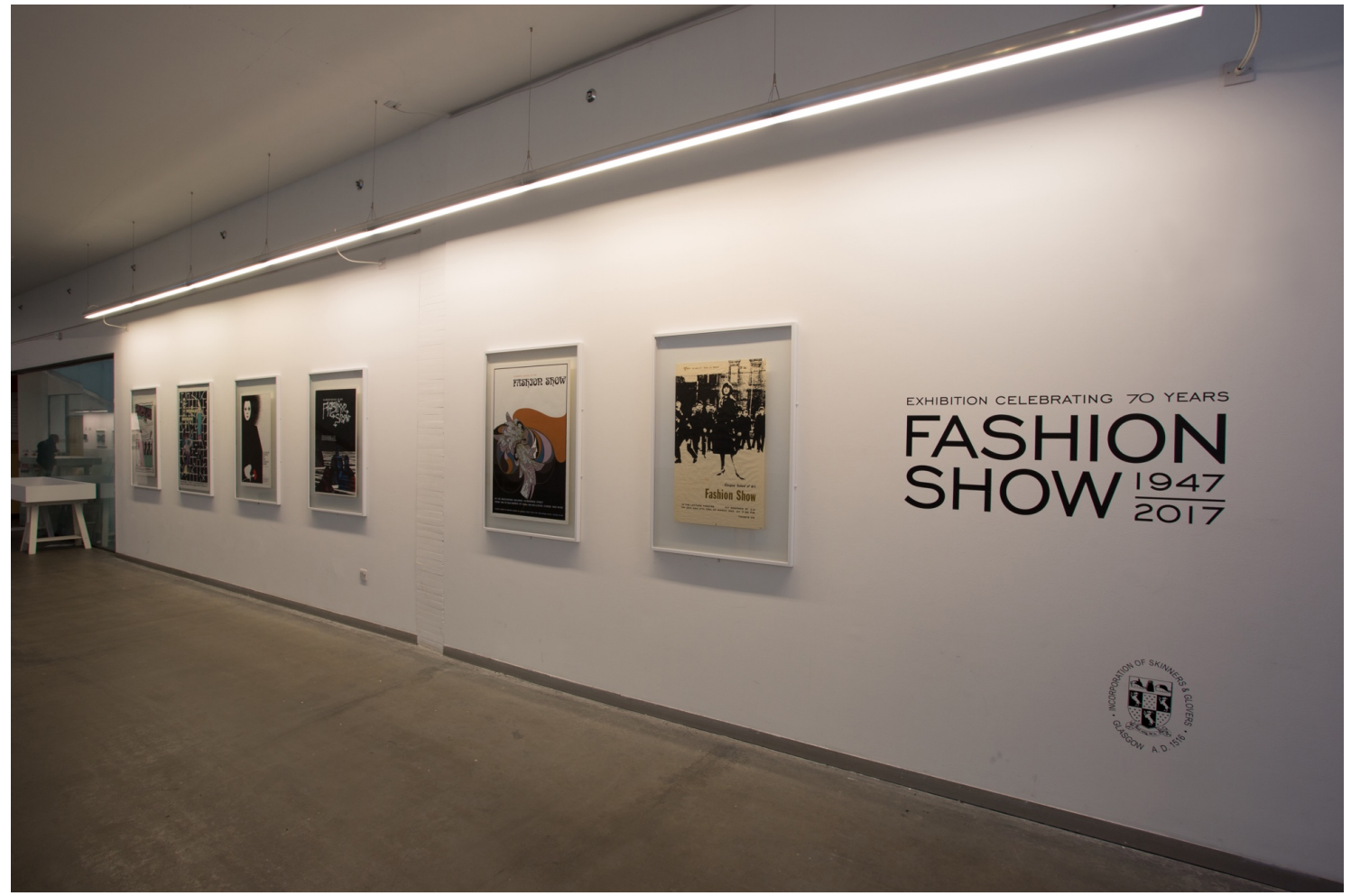

Figure 2. GSA Fashion Show $70^{\text {th }}$ Anniversary Exhibition framed works, Reid Building, Glasgow School of Art, UK, $4^{\text {th }}-26^{\text {th }}$ March, 2017. Photograph by Jack McCombe.

\section{GSA Fashion Show as Evolving Pedagogy}

From $\mathrm{A} \& \mathrm{C}$ material and alumni insights, it has been possible to construct a working timeline of the GSA fashion show, Table 1 shows an edited version. Analysis has involved extracting data which indicates developments in the history of the event, contributions to student learning and the evolution of textile and fashion design teaching at the School; these findings are discussed chronologically in the subsequent sections. 


\begin{tabular}{|c|c|}
\hline Year & GSA Fashion Show Department Involvement and Show Them e/s \\
\hline 1947 & GSA and Dough School. Garments made from purchased fabrics. \\
\hline 1948 & GSA and Dough School; Academy of Music. Modern designs, historical recreation, accessories. \\
\hline 1949 & GSA. Modern designs, historical recreation, material reuse, upcycling, accessories. \\
\hline 1950 & GSA. Modern designs, material reuse, purchased fabrics, accessories. \\
\hline 1951 & GSA. Modern designs, material reuse, purchased fabrics, accessories. \\
\hline 1952 & Printed Textiles, other Departments. Modern designs, material reuse and purchase, male models. \\
\hline 1953 & Printed Textiles, other Departments. Hand-woven and -printed fabrics, upcycling, S\&J accessories. \\
\hline 1954 & Printed Textiles, other Departments. Modern design, inexpensive fabrics, upcycling, accessories. \\
\hline 1955 & Printed Textiles, other Departments. Modern design, inexpensive fabrics, upcycling, accessories. \\
\hline 1956 & Textiles, other Departments. Modern design, inexpensive fabrics, upcycling, accessories. \\
\hline 1957 & Textiles, other Departments. Modern design, upcycling, accessories. \\
\hline 1958 & Textiles, other Departments. Modern design, upcycling, accessories. \\
\hline 1960 & Textiles, Departments. Unusual materials, fantasy clothes, coordinating hats. \\
\hline 1961 & Textiles, other Departments. Interior Design décor. Unusual materials, final year lengths. \\
\hline 1962 & Textiles, other Departments. Textile Design décor. Wearable and commercial garments. \\
\hline 1963 & Textiles, other Departments. Wearable and commercial garments. \\
\hline 1964 & Textiles, other Departments. Wearable and commercial garments. \\
\hline 1965 & Textiles. Commercial and industry-focused designs, increased professionalisation. \\
\hline 1966 & Textiles. Commercial and industry-focused designs. \\
\hline 1967 & Textiles. Commercial and industry-focused designs, professional finish. \\
\hline 1968 & Textiles, other Departments. Commercial and industry-focused designs. \\
\hline 1969 & Textiles. Commercial and industry-focused designs, featured garments for Pringle. \\
\hline 1970 & Part of GSA's first Action Week. Printed, Woven, Embroidered Textiles garments. \\
\hline 1971 & Part of Scottish Education Department Centenary. Printed, Woven, Embroidered Textiles garments. \\
\hline 1972 & Textiles, other Departments. Printed, Woven, Embroidered Textiles garments. \\
\hline 1973 & Textiles, other Departments. Printed, Woven, Embroidered Textiles garments. \\
\hline 1974 & Textiles, other Departments. Architecture set design and build. \\
\hline 1975 & Textiles. Textiles garments. \\
\hline 1976 & Textiles, other Departments. Drawing \& Painting, Graphics, Industrial Design, Jewellery garments. \\
\hline 1977 & Textiles. Printed, Embroidered \& Woven Textiles, Product Design, Drawing \& Painting garments. \\
\hline 1978 & Textiles. Printed, Embroidered \& Woven Textiles, Graphics, recent alumni garments. \\
\hline 1979 & $\begin{array}{l}\text { Textiles, other Departments. Printed Textiles graphics. Printed, Embroidered \& Woven Textiles, S\&J, recent } \\
\text { alumni garments }\end{array}$ \\
\hline 1980 & $\begin{array}{l}\text { Textiles, other departments. Printed Textiles graphics. Printed, Embroidered \& Woven Textiles, Mixed } \\
\text { Media, Murals and Graphics, recent alumni garments. }\end{array}$ \\
\hline 1982 & GSA SRC, other Departments. Costume/theatrical emphasis and wearable garments. \\
\hline 1983 & GSA SRC, other Departments. Costume/theatrical emphasis and wearable garments. \\
\hline 1984 & GSA SRC, other Departments. Costume/theatrical emphasis and wearable garments. \\
\hline 1985 & GSA SRC, other Departments. Costume/theatrical emphasis and wearable garments. \\
\hline 1986 & $\begin{array}{l}\text { Part of Activities Week. GSA SRC, other departments. Royal Scottish Academy of Music and Drama } \\
\text { designed and constructed set. Costume/theatrical emphasis and wearable garments. }\end{array}$ \\
\hline 1987 & $\begin{array}{l}\text { GSA SRC, other departments. Set by Interior Design and poster by Printed Textiles. } \\
\text { Costume/theatrical emphasis and wearable garments produced as part of Textiles projects. }\end{array}$ \\
\hline 1989 & $\begin{array}{l}\text { GSA SRC, other Departments. Printed, Embroidered \& Woven Textiles, S\&J, Graphics, Interior Design, } \\
\text { Sculpture, Industrial Design, Architecture, Environmental Art, Drawing \& Painting garments. }\end{array}$ \\
\hline 1990 & Textiles. Support from GSA SRC. \\
\hline 1991 & Textiles. Support from GSA SRC. \\
\hline 1995 & Limited evidence. GSA SRC activity. \\
\hline 1996 & Limited evidence. GSA SRC activity. \\
\hline 1997 & Limited evidence. Printed \& Knitted Textiles, Embroidered \& Woven Textiles garments. Material reuse. \\
\hline 1998 & $\begin{array}{l}\text { Part of Glasgow City of Architecture and Design. Textiles. Theme: Morphogenesis. Printed \& Knitted } \\
\text { Textiles, Embroidered \& Woven Textiles garments. Video projections by Interior Design. }\end{array}$ \\
\hline
\end{tabular}




\begin{tabular}{|c|c|}
\hline 1999 & $\begin{array}{l}\text { Textiles. Theme: Morphogenesis '99. Textiles - Print, Weave, Embroidery, Knit (PWEK) garments. Video } \\
\text { projections by Interior Design, sound by NVA. }\end{array}$ \\
\hline 2000 & Textiles. Theme: 24 hours. Textiles (PWEK) garments. Set by Interior Design and sound by NVA. \\
\hline 2001 & Textiles. Textiles (PWEK) garments. \\
\hline 2002 & $\begin{array}{l}\text { Textiles. Textiles (PWEK) garments. Increased time in Textiles undergraduate curriculum for fashion show } \\
\text { garment design and production. }\end{array}$ \\
\hline 2003 & Textiles organised. Textiles (PWEK) and PhD student garments. \\
\hline 2004 & $\begin{array}{l}\text { Professional Skills project for Textiles, with GSA Careers Services. Theme: 'Mannequin' with J. Roberts and } \\
\text { S. Chen. Textiles (PWEK) garments. Boutique extra-curricular project. GSASA supported. }\end{array}$ \\
\hline 2005 & $\begin{array}{l}\text { Professional Skills project for Textiles, with GSA Careers Services. Theme: de- and re-construction. Textiles } \\
\text { (PWEK) garments. Boutique extra-curricular project. GSASA supported. }\end{array}$ \\
\hline 2006 & $\begin{array}{l}\text { Professional Skills project for Textiles, with GSA Careers Services. Theme: ‘Stacey’s Face’ film script/ } \\
\text { sustainability. Textiles (PWEK) garments. Boutique extra-curricular project. GSASA supported. }\end{array}$ \\
\hline 2007 & $\begin{array}{l}\text { Professional Skills project for Textiles, with GSA Careers Services. Theme: upcycling, supported by Cancer } \\
\text { Research UK. Textiles (PWEK) garments. Boutique extra-curricular project. GSASA supported. }\end{array}$ \\
\hline 2008 & $\begin{array}{l}\text { Professional Skills project for Textiles, with GSA Careers Services. Poster with Graphic Design. Theme: } \\
\text { 'Avant Garde' with J. Roberts. Textiles (PWEK) garments. Boutique extra-curricular project. GSASA } \\
\text { supported. }\end{array}$ \\
\hline 2009 & $\begin{array}{l}\text { Professional Skills project for Textiles, with GSA Careers Services. Filmed by Popmorphic. Textiles (PWEK) } \\
\text { garments. Boutique extra-curricular project. GSASA supported. }\end{array}$ \\
\hline 2010 & $\begin{array}{l}\text { Professional Skills project for Textiles, with GSA Careers Services. Textiles (PWEK) garments. Boutique } \\
\text { extra-curricular project. GSASA supported. Window display. }\end{array}$ \\
\hline 2011 & $\begin{array}{l}\text { Professional Skills project for Textiles, with GSA Careers Services. Theme: Newbery Tower. Textiles } \\
\text { (PWEK) garments. Boutique extra-curricular project. GSASA supported. Window display. }\end{array}$ \\
\hline 2012 & $\begin{array}{l}\text { Professional Skills project for Textiles and Fashion, with GSA Careers Services. Textiles (PWEK) and } \\
\text { Fashion garments. Boutique extra-curricular project. GSASA supported. Window display. }\end{array}$ \\
\hline 2013 & $\begin{array}{l}\text { Professional Skills project for Textiles and Fashion, with GSA Careers Services. Themes: Black Dress/White } \\
\text { Shirt, Androgyny/Harris Tweed, 'Rite of Spring' (Royal Conservatoire of Scotland/BBC Scottish Symphony } \\
\text { Orchestra). Fashion and Textiles (PWEK) garments. Boutique extra-curricular project. GSASA supported. }\end{array}$ \\
\hline 2014 & $\begin{array}{l}\text { Professional Skills project for Textiles and Fashion, with GSA Careers Services. Theme: Lace. Fashion and } \\
\text { Textiles (PWEK) garments. Boutique extra-curricular project. GSASA supported. }\end{array}$ \\
\hline 2015 & $\begin{array}{l}\text { Professional Skills project for Textiles and Fashion, with GSA Careers Services. Themes: Non-western world } \\
\text { dress traditions, cultural appreciation. Fashion and Textiles (PWEK) garments. Boutique curriculum project. } \\
\text { GSASA supported. }\end{array}$ \\
\hline 2016 & $\begin{array}{l}\text { Professional Skills project for Textiles and Fashion, with GSA Careers Services. Themes: Geometry, gender } \\
\text { neutrality. Poster with Graphic Design; staging and lighting with Architecture and Interaction Design. Fashion } \\
\text { and Textiles (PWEK) garments. Boutique curriculum project. GSASA supported. }\end{array}$ \\
\hline 2017 & $\begin{array}{l}\text { Professional Skills project for Textiles and Fashion, with GSA Careers Services. Theme: } 1947-2017 / 70^{\text {th }} \\
\text { Anniversary. Poster with Graphic Designer. Fashion and Textiles (PWEK) garments. Boutique curriculum } \\
\text { project. GSASA supported. }\end{array}$ \\
\hline
\end{tabular}

Table 1. GSA Fashion Show Department Involvement and Show Theme/s.

\section{The Late 1940s - Collaborative Parades}

Newspaper reports from 1947 state that the first GSA fashion show involved "...more

than 30 different outfits specially made for the parade." (The Daily Express 1947:

unknown) The event was a collaboration between female students from the School of

Art and West of Scotland College of Domestic Science (or 'Dough School' as it was

known). The Dough School was established in 1908, combining the Glasgow School of

Cookery (1875) and the West End School of Cookery (1878); in addition to cookery,

other courses at the School included dressmaking, needlework and millinery (Glasgow

Caledonian University 2018). At the inaugural fashion show, the students modelled 
their creations, in aid of Charities Week, a Glasgow-wide fundraising event. An art school student was credited with the smooth running of the show and commentary by staff member Jack Fleming accompanied the parade. Fraser (1991: 19) describes the rationale for the first GSA Fashion Show as "... a mystery..." due "...to the fact that several parties all claim the credit for its inception." The Dough School could have introduced the event to GSA; four female GSA drawing and painting students may have established the show; due to potential to generate funds, it could have been set up as a School charity event; or it was formed by a student who had connections to the Glasgow rag trade (Fraser 1991).

In 1947, activity at GSA centered around the Day School, there was also an Evening School, classes for art teachers and children, and instruction in architecture (GSA 1947). Diploma courses lasted four to five years, comprising a general course studied for two years and specialized study for a further two years, options included Embroidery and Weaving or Textile Design and Fabric Printing (GSA 1947). Evening classes were available in Fashion Design, Historic Costume and Design; Embroidery and Design; Textile Design and Block Printing (GSA 1947). Connection with the Dough School could have been due to these students coming to GSA to take classes. The exact rationale for the inception of the show is currently unknown, although it is likely that the event evolved, post-World War II for fundraising purposes, and from the popularity of costume making and fancy-dress parades, often part of GSA social events.

Collaboration with Dough School students continued for the 1948 fashion show. GSA student's made garments, the Dough School catered and music was supplied by a trio 
from the Academy of Music (The Herald 1948). For this show modern designs were presented alongside historical recreations; this focus remained for 1949:

"They worked from original sketches by School of Art lecturer on historic costume Jack Fleming...the gowns will be true replicas in every detail...Slippers, gloves and jewellery to suit each outfit will also be made in the School of Art. After the 'curtain raiser' of historic dress, modern clothes designed and displayed by the students will be shown." (Evening Citizen 1949: unknown)

Historic garment replication and new design creation included material reuse and garment upcycling, as old Army blankets, velvet curtains and an outdated dress were used to make garments (Evening Citizen 1949). Making for this show took place over the Christmas holidays, indicating the extracurricular nature of the event (Evening Citizen 1949).

In September 1948, Kathleen Whyte began as embroidery and weaving lecturer at GSA and set about revising course content despite material shortages and a lack of equipment due to rationing (Arthur 1989). Whyte made her clothes and “...because of wartime restrictions, she began weaving material for her mother, sister and friends, creating the fabric to suit the personality of the wearer." (Arthur 1989: 36) In 1949, Robert Stewart joined GSA to take charge of the Printed Textile Department, followed by the appointment of Bill Barmer as Print Technician, and the acquisition of specialist screenprinting equipment (Arthur 2003). 


\section{The 1950s - Resourceful Organisation}

Whyte introduced machine embroidery and tapestry weaving to GSA in 1950 (Arthur 1989), her influence and that of Stewart's will have informed the work that students produced for the fashion show. Stewart may have recognized the value of the show to student learning as, during the early 1950 s the event “.... was organized and run by the Printed Textile department students." (Schoeser 2003: 90) The fashion show provided textile students with the opportunity to focus on garment making and utilize their organizational skills, if part of the committee for the event:

"As convener of the Committee, Miss [Betty] Stewart does more than merely organise. Her ideas in dress are quite brilliant. I've told you how she turned ordinary sackcloth into modish garments. Now, she works wonders with an Army greatcoat, a piece of wire netting and two oddments of cloth-ocelet fabric and black velour." (Petrie 1952: 8)

Approximately 20 students worked together to organise the 1952 fashion show, the first to feature male mannequins, paraded on stage in front of a painted backdrop. Reports from the coronation themed 1953 show mention the making skills developed during students' studies: "The show includes abundant evidence of the serious classroom instruction, with suits and jackets of handwoven fabrics and dresses of materials both handwoven and hand-printed in the college" (Evening Times 1953: unknown); "Not only are the dresses designed and made by the girls, but some of the fabrics are printed and woven in the school. Even the jewellery is made in the school silversmiths' department." (Philpott 1953: 12) 
Fashion show programmes for 1953 (Figure 3) and 1955 (Figure 4) list committee members as convenor, a team of associates, stage director, publicists, treasurer, electricians, compere, graphic designer and mannequins. The programmes promote the shows sponsors as "Lancôme of Paris" for make-up and "Kayzer Bondor" for nylon stockings (GSA 1953, 1955). Changes to the fashion show in the early 1950s attempted “...to capture a wider audience...”, the “...new look production ran for three nights the two public nights were still decidedly formal...with...Jack Fleming...excellently comparing the whole event..." while the "...student night...was a totally different affair...", described as a “...boisterous occasion...” (Fraser 1991: 23-24). Shows during this era tended to take place in GSA's Assembly Hall. Up until 1958, the GSA fashion show continued to be part of Charities or Rag Week, however during this year the timing of the event changed, money was still raised for various charities but the Glasgow-wide Charities Week is not mentioned.

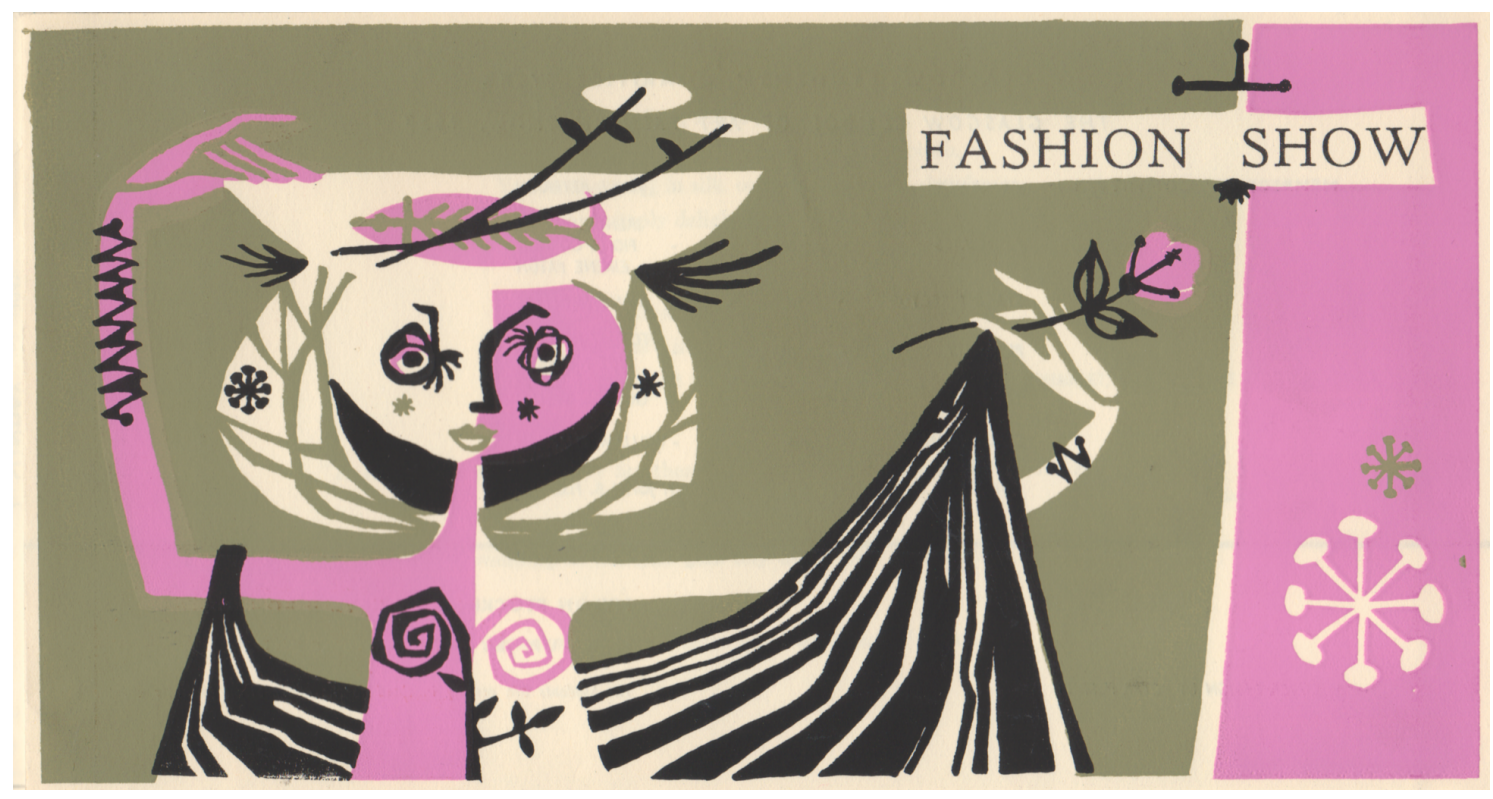

Figure 3. GSA Fashion Show programme cover 1953, designed by Peter Perritt.

Courtesy of The Glasgow School of Art Archives \& Collections, GSAA/EPH/1. 




Figure 4. GSA Fashion Show programme cover 1955, designed by Robert MacGowan.

Courtesy of The Glasgow School of Art Archives \& Collections, GSAA/EPH/1.

\section{The 1960s - Experimental to Industry-Focused}

Records from May 1960 explain that the Students' Fashion Show collected a recordbreaking sum of almost $£ 60$, divided among Roosevelt Memorial (Polio) Fund, Cancer Relief Fund and The World Refugee Year. Profits from the 1961 and 1962 shows went to other charities, and those from 1963 went to 'War on Want', highlighted on the poster for this year, the earliest held by A\&C (GSA 1963). Early 1960s shows appear to be about fundraising, experimentation and enjoyment for both students and audience. Textile students were “...encouraged to explore different areas such as fantasy clothes and fashion illustration as well as fashion textiles." (Schoeser 2003: 90) Hats made for the show attracted media attention due to their outlandish styles and unusual materials:

“About 70 dresses, nearly all with matching hats, will be on show...These girls don't stop at ordinary fabrics, oh dear me, no. Wood shavings, cigarette packets...nylons...they've all be used to make the most eye-catching fashions Glasgow's seen for a long time...Crazy? Of course they're crazy. Wonderfully crazy. 
It wouldn't be an art school fashion show if the dresses weren't as cock-eyed and fantastic as possible." (The Bulletin 1960: unknown)

There is mention of a silk screen printed fabric featuring in the fashion show, “...preserved uncut for display at the end of the year, so its owner has simply pinned it into an elegant coat with no stitching at all" (Brown 1961: unknown), suggesting that final year students contributed to the show by presenting work created as part of their course. Those responsible for the set design of the event varied, as in 1961 the décor was produced by the Department of Interior Design and for 1962 by the Textile Department.

Whyte and Stewart visited and assessed other Schools in England, which informed their teaching (Arthur 1989). During the 1960s, Stewart set about making contacts with industry which influenced student projects (Schoeser 2003). In 1963 a color chemist, Julius Tescher was appointed, he introduced new dyes and expertise to Printed Textiles (Arthur 2003). The following year, in addition to an existing technical assistant, a fulltime weaving assistant was hired (Arthur 1989). In 1965, staff with expertise in fashion and pattern cutting were appointed (Schoeser 2003). The influence of commercial, industry-based, technical and material developments to the design and production of garments is evident in reports from the mid-1960s:

'Every spring Glasgow School of Art students stage a fashion show. Usually it's a crazy affair which takes the mickey out of current trends. But...this year's show has a different aim - to show that Scottish fashion designing might eventually take its place alongside that of London, Paris, and Rome...this year we are staging a serious fashion 
show as an indication that original fashion design can stem from art school students in Glasgow.", (Munro 1964: 6)

The 1965 show included garments commissioned by British Nylon Spinners and previously displayed in London:

'It used to be good for a giggle, an effective way of cheering up the dull, dark winter evenings. This year's fashion show by the Glasgow School of Art remains excellent entertainment, but it can no longer be dismissed as a joke in mixed taste... But this change in taste is a result as much as a cause - it stems from the upsurge of young feeling which persuaded commercial manufacturers to go to the art schools for new designs.' (Reid 1965)

The GSA prospectus $1964 / 65$ is the first to include photographs and features images from the fashion show (Figure 5), which involved 60-70 outfits worn by 18 female student models (GSA 1964: 6). Under 'Student Activities', a GSA annual report emphasizes the increased professionalism of the event: “...one of the most polished and creative fashion shows ever held..." (GSA 1965: 17). Five students comprised the 1967 fashion show committee, described by GSA's Director as “...even more professional in finish and remarkable for some very good men's clothes. Unfortunately, they ended up with a considerable financial loss...for the first time." (GSA 1967: 15) Programmes and posters from this time make no mention of the fundraising aspect of the show. For the 1968 event held in the School Museum, the annual report explains "...the Fashion Show had a particularly successful season, ending up with a special show in Culzean Castle, in order to try and raise funds for the appeal." (GSA 1969a: 16) The "funds for the 
appeal" mentioned could refer to the cost of holding the show or fundraising for study trips to the Culzean Castle hostel and studio which the School opened in 1967.

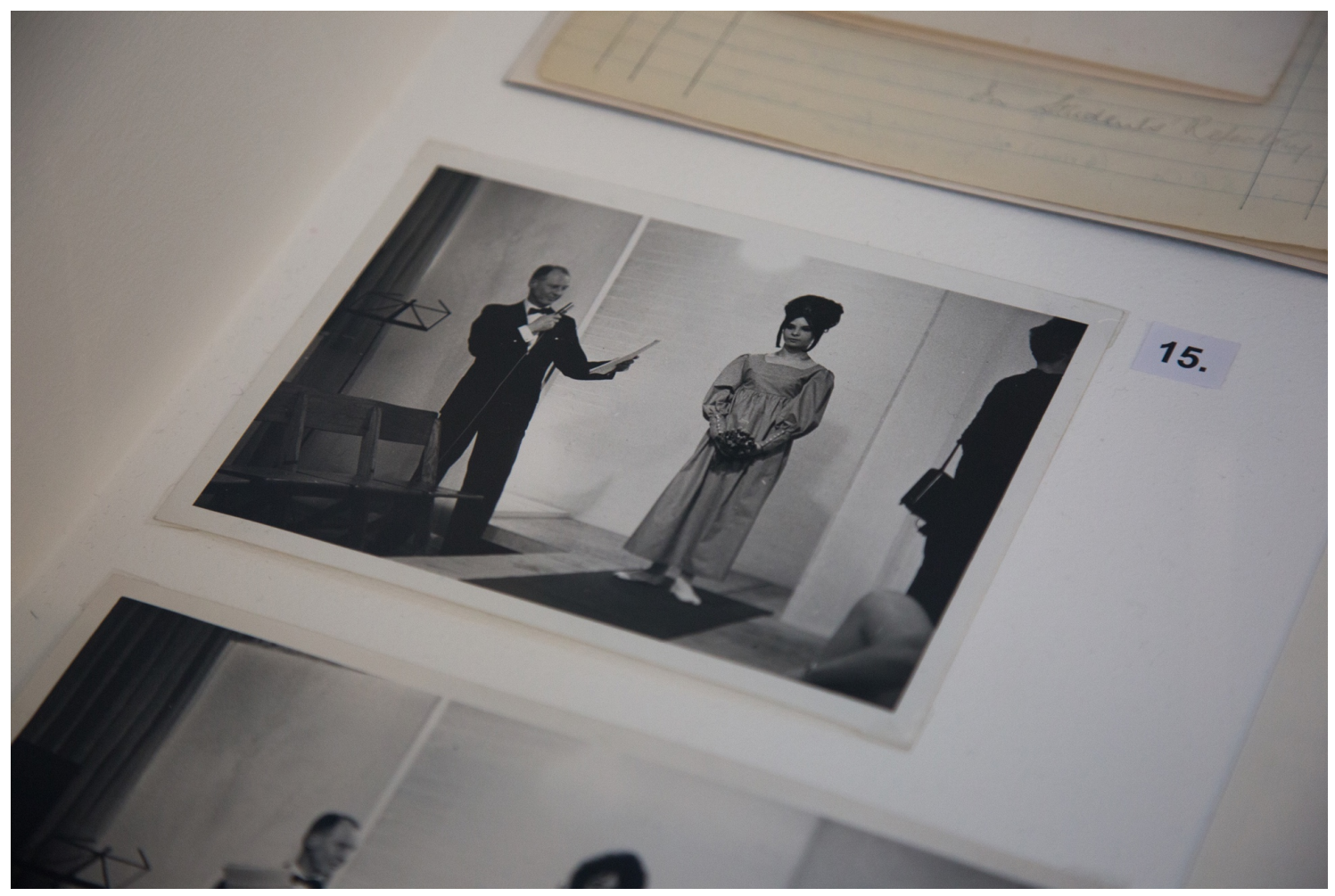

Figure 5. GSA Fashion Show $70^{\text {th }}$ Anniversary Exhibition vitrine displaying GSA Archives \& Collections photographs from 1964, GSAA/P/1. Photograph by Jack McCombe.

The 1968 fashion show student director role included “...dress making, design, lighting, models, and make-up...”, viewed by this student as “.... an essential part of...practical training for students..." and a valuable experience for life after graduation (Young 1968: unknown). The 1969 preview show was held at the Scottish Design Centre followed by a week-long run of shows at the Art School (Daily Express 1969), which included “...twelve printed cashmere garments designed in the Textile Department and made by Pringle of Hawick" (GSA 1969b: 34) (Figure 6). During the late 1960s, although there are links with work produced by students as part of the curriculum and student organization of the show appears to be valued as a learning experience, the GSA 
prospectus states: “...the Annual Fashion Show is the culmination of many months of designing, cutting and making. The entire organisation and modelling is undertaken by students in their own time." (GSA 1969b: 23; 1970: 24; 1971a: 26)

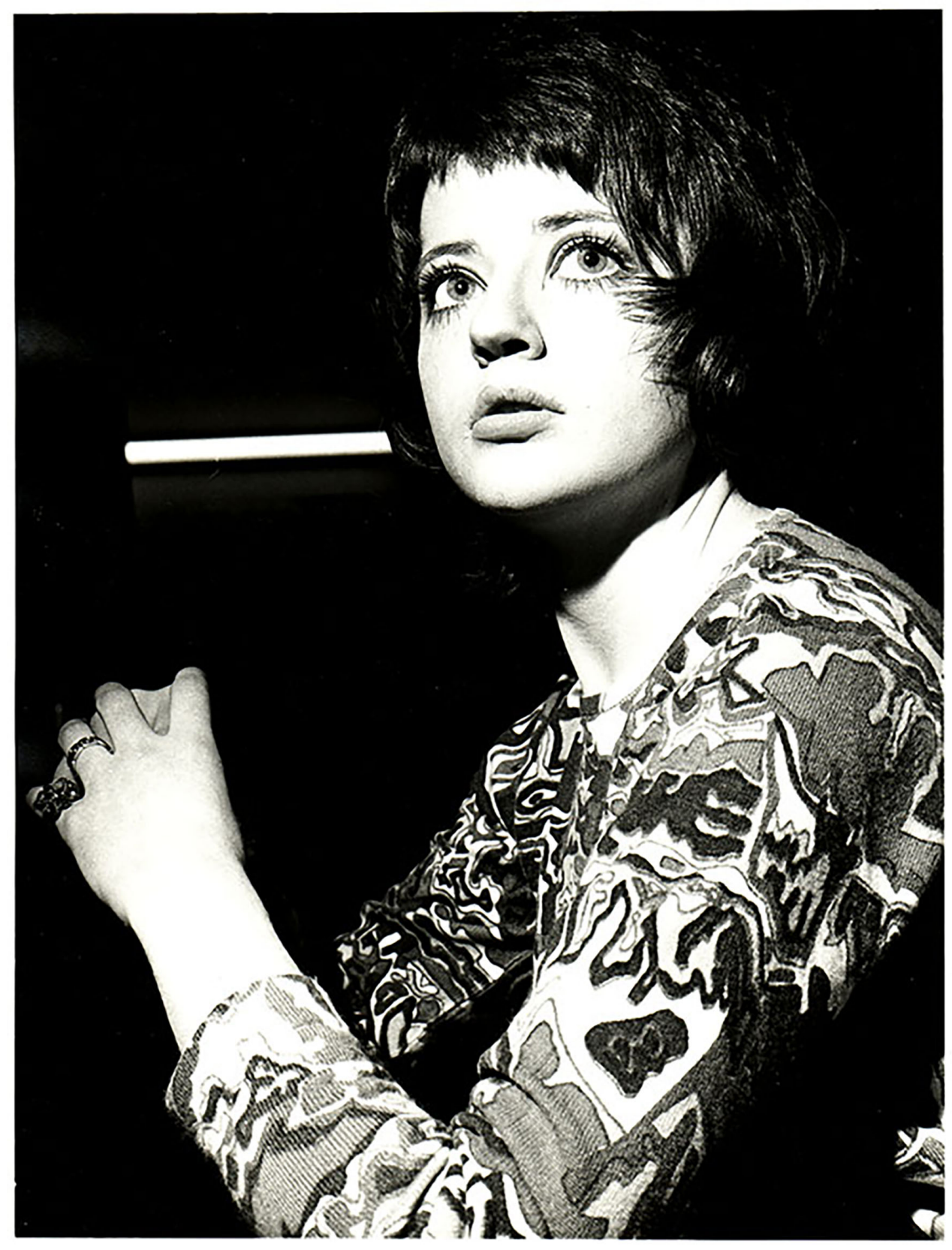

Figure 6. Anne Howatson modelling GSA student Alex Gourley's Pringle cashmere sweater, c1960. Courtesy of The Glasgow School of Art Archives \& Collections, GSAA/P/1. 


\section{The 1970s - Changing Identities}

There was change at GSA in the early 1970s, times of economic hardship paralleled the opening of new buildings. The School's 'Action Week' (later changed to 'Activities Week') was introduced, which provided a break from the scheduled curriculum to engage in events such as workshops and talks by well-known practitioners. The most significant changes were proposals made “...to revise the Diploma Courses and to introduce the Associateship Courses with honours...” (GSA 1971b: 14). From 1971/72 students took a one-year general course, followed by three years of specialised study (GSA 1970). Within Design, subjects for specialist study included Embroidery and Weaving, and Textile Design. Revised descriptions for these courses mention new and updated spaces and facilities, innovative developments in dress embroidery due to industrial sewing machines, design concerning woven fashion fabrics, and the production of printed dress fabrics (GSA 1970), but course descriptions do not mention the fashion show as part of the student learning experience. Even though, at this time, the “...GSA's annual fashion show provided a show case... and was an important event..." (Schoeser 2003: 90).

The 1970 show is described as “...rather a spectacular occasion. Flashing lights in psychedelic patterns and colors are the background to space-age cloaks and tunics designed and modeled by the students." (Nicol 1970: unknown) Geometric and embroidered textile designs featured on garments and 'robes for men' (Figure 7). Costumes are included, and one created by a fourth-year student is noted as winning a national competition (Nicol 1970), highlighting the showcase nature of the event. For $1971 / 72$, there was an additional dimension as the show was used to represent the School at the Scottish Education Department's Centenary Celebrations: "Never, I think, have so many of the outfits been made of materials either printed, woven, or 
embroidered in the School...: (GSA 1972: 13). The Director also mentions the fashion show in subsequent annual reports:

“...continuing a long and unbroken tradition, the students staged another most successful fashion show. Although an essentially student motivated activity, the current interest in dress fabrics in both the textile areas of the School greatly helps the highly professional standards achieved in some of the garments modelled." (GSA 1973: 16)

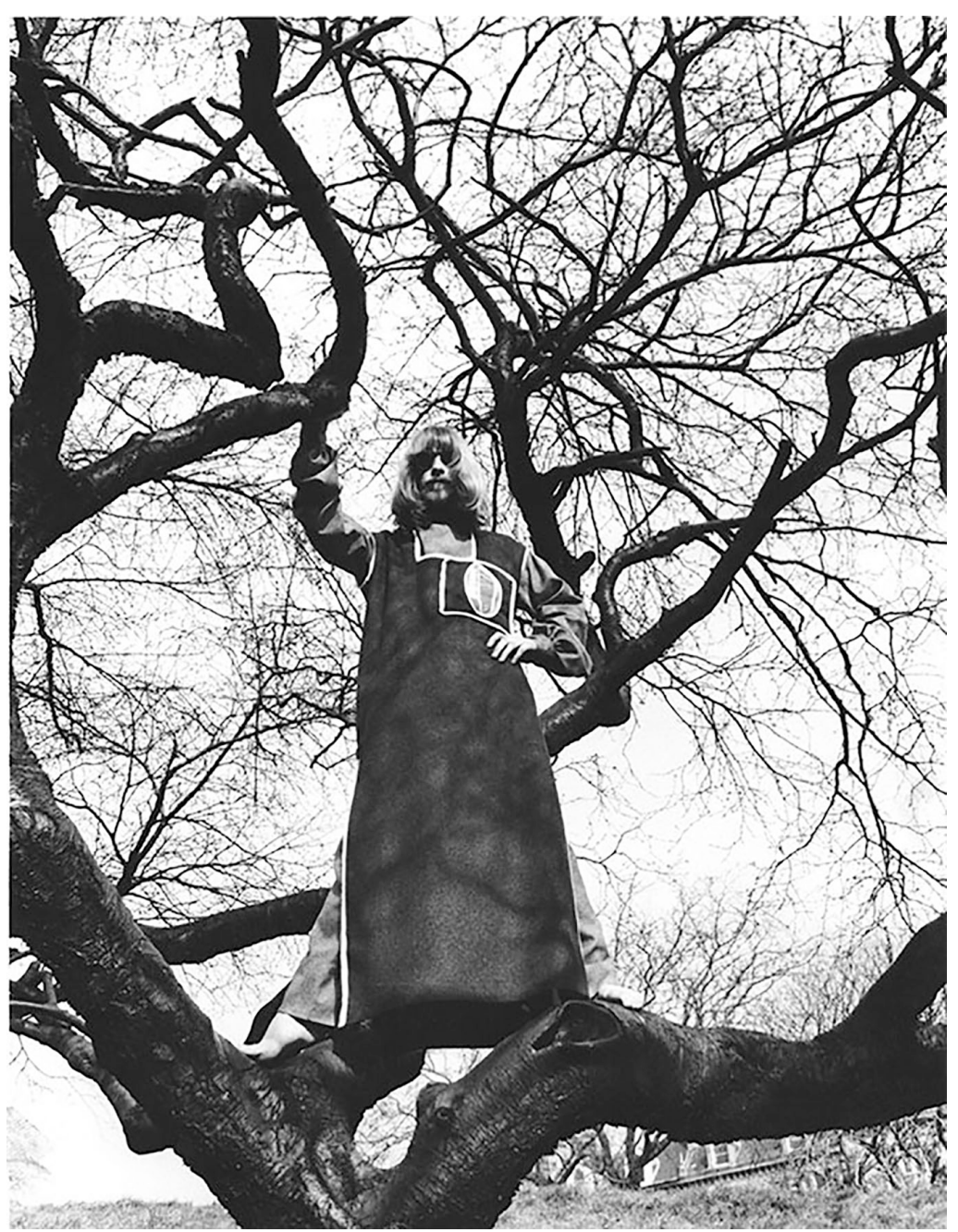

Figure 7. GSA student, John McKechnie modelling his design for a tunic, 1971.

Courtesy of The Glasgow School of Art Archives \& Collections, GSAA/P/1. 
It appears that the fashion show and other student-led events such as Drama Club, influenced Activities Week and there is recognition by GSA's Director of the overlap between curricula and extra-curricular learning:

“...the Textile Section took a major part in mounting the Students' Annual Fashion Show...It is extremely encouraging that the student's Fashion Show, which is not part of the official programme of the School, has continued with such unabated vigour...I am often tempted to think that one should be able to gauge the health of a school by the quality and diversity of its extra-mural activities...[in] an art school...a great deal of the so called formal work is, in fact, done under very informal conditions, and there is not sharp division between what is essentially course work and what is done in the student's own time." (GSA 1974: 18-19)

In the early 1970s, Jimmy Cosgrove was appointed to teach Textile Design. In 1974, Whyte retired from Embroidery and Weaving and this department came under the leadership of Crissie White (Arthur 1989). In this year, the fashion show took place in GSA's Haldane Building, “...Third Year students of the Textile Section constituted the committee responsible for the Fashion Show...Students from the Department of Architecture collaborated in the design and building of the setting." (GSA 1975: 23) Schoeser (2003: 90) states that in the 1970s the fashion show “...was taken over by the Student Representative Council." However, the impact of this change is currently unknown, as reports from the mid to late 1970s continue to suggest organizational contributions from textiles students and staff. Staff member Carol Paterson explained that the majority "...of the garments have been designed by students from the Textile Department but many are from first year students who haven't specialised." (Glasgow 
Herald 1975: 9) The 1976 show took place at the Third Eye Centre; the GSA Director reported “...the annual students' fashion show is by no means a structured part of the curriculum...it owes a great deal of its quality and inventiveness to the participation of the Textiles Section." (GSA 1976: 21) The involvement of students from other departments is apparent, from drawing and painting, graphics, industrial design, embroidery and jewellery (Moore 1976).

Graphic design and print media influences within the School are evident through the changing visual identity of fashion shows from this era. Themes were translated into corresponding posters, programmes and set design. The 1977 'Fashion Circus' show took place in the Haldane Building, models paraded in a circus ring, on a floor of sawdust and a person dressed in gorilla costume provided additional entertainment: "To pounding Big Top music...the scope provided by the circus theme has revealed rich reserves of innovation plus plenty of technical know-how." (Anon 1977). The screenprinted fabric poster for this event uses fairground-like fonts and motifs in bold colors. The 1978 fashion show took place in the Mackintosh Lecture Theatre, the synchronizing visual identity is apparent across poster (Figure 8), programme and ticket, the show's compare wore a coordinating red carnation in his lapel. For the 1979 show held in GSA's Bourdon Building, graphic posters, programmes and printed backdrops were created by a postgraduate student who also produced a collection of printed garments with similar aesthetic qualities. The 1980 poster and programme were designed by a printed textile undergraduate, indicating the cross-over of textiles into graphics. 


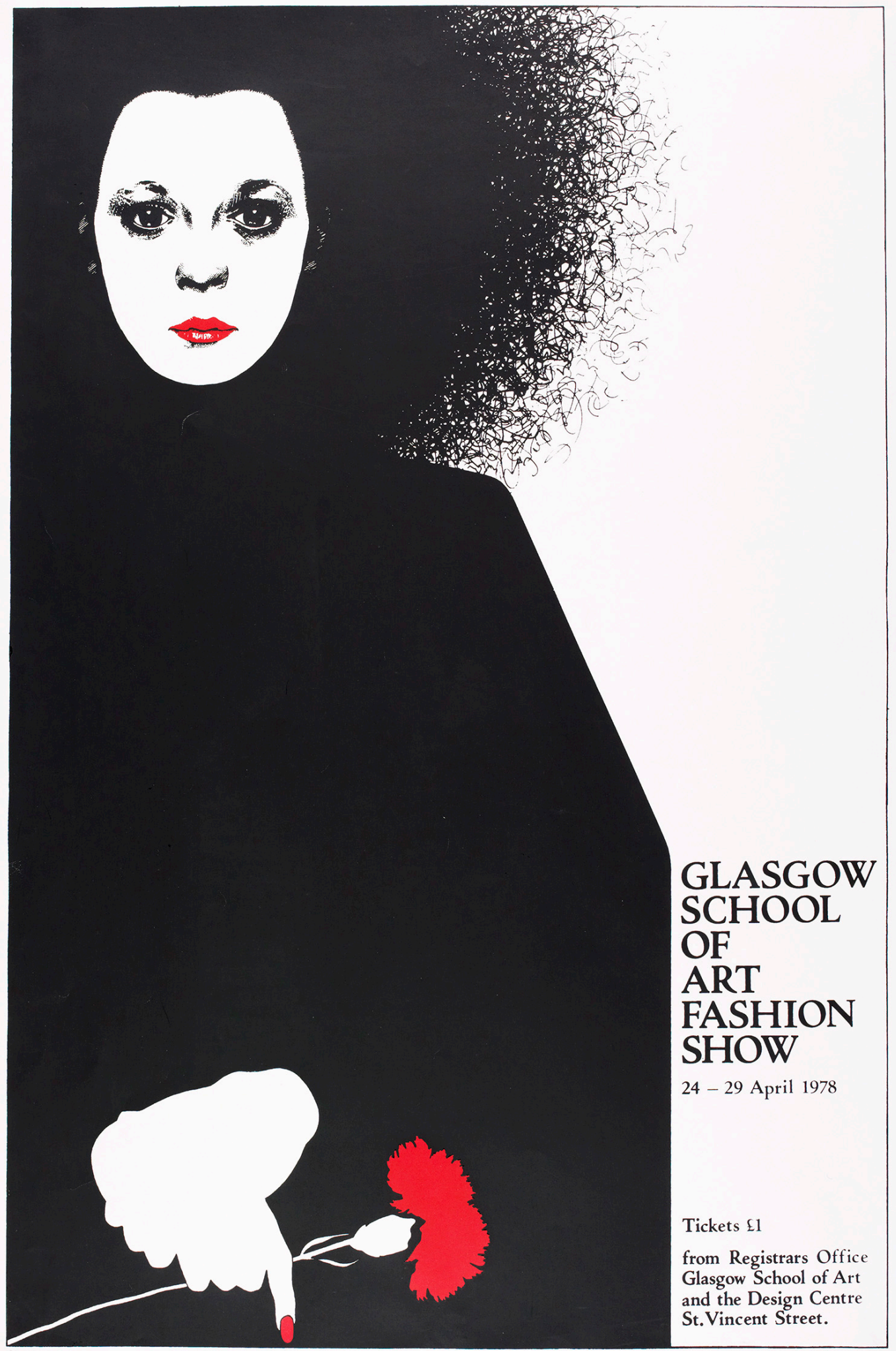

Figure 8. GSA Fashion Show poster 1978, designed by Colin Watson. Courtesy of The

Glasgow School of Art Archives \& Collections, GSAA/EPH/10/58. 
Programmes from this period state that garments could be purchased from students via the relevant Department. It is evident that this era of fashion shows provided opportunities for organizational learning, cross-disciplinary design and income generation. However, revised course descriptions in GSA prospectuses introducing the new BA and BA (Honours) Degree (GSA 1978a) and MA Design (GSA 1980) courses make no mention of the event as contributing to student learning. Towards the end of the 1970s, Cosgrove took over Printed Textiles, as Stewart, in addition to being Head of the MA course, became Head of the School of Design (GSA 1978b, Arthur 2003). Stewart had been central to facilitating collaborations with the Scottish knitwear industry and industrial knitting machines had been introduced. The use of this equipment is evident in some 1970s and 1980s fashion show photographs.

\section{The 1980s - Performance and Commerciality}

There is a wealth of ephemera representing the 1980 fashion show due to alumni donations (Figure 9). Although to date, it has not been possible to build a comprehensive account of GSA fashion shows throughout this era. Access to archived annual reports from this period is restricted. News cuttings provide scant information as they feature large photographs and accompanying brief descriptions. There is only one GSA prospectus for the 1980s, it states:

"The annual Fashion Show, one of the highlights of the session, is the culmination of many months of designing, cutting and making. In existence for a considerable number of years, it is widely supported by the Glasgow public and gets a very good Press coverage. The main work is done by Textiles and Embroidery students, but there is hardly a department in the School whose students have not contributed. The entire organisation is undertaken by the students in their own time." (GSA 1980: 57) 


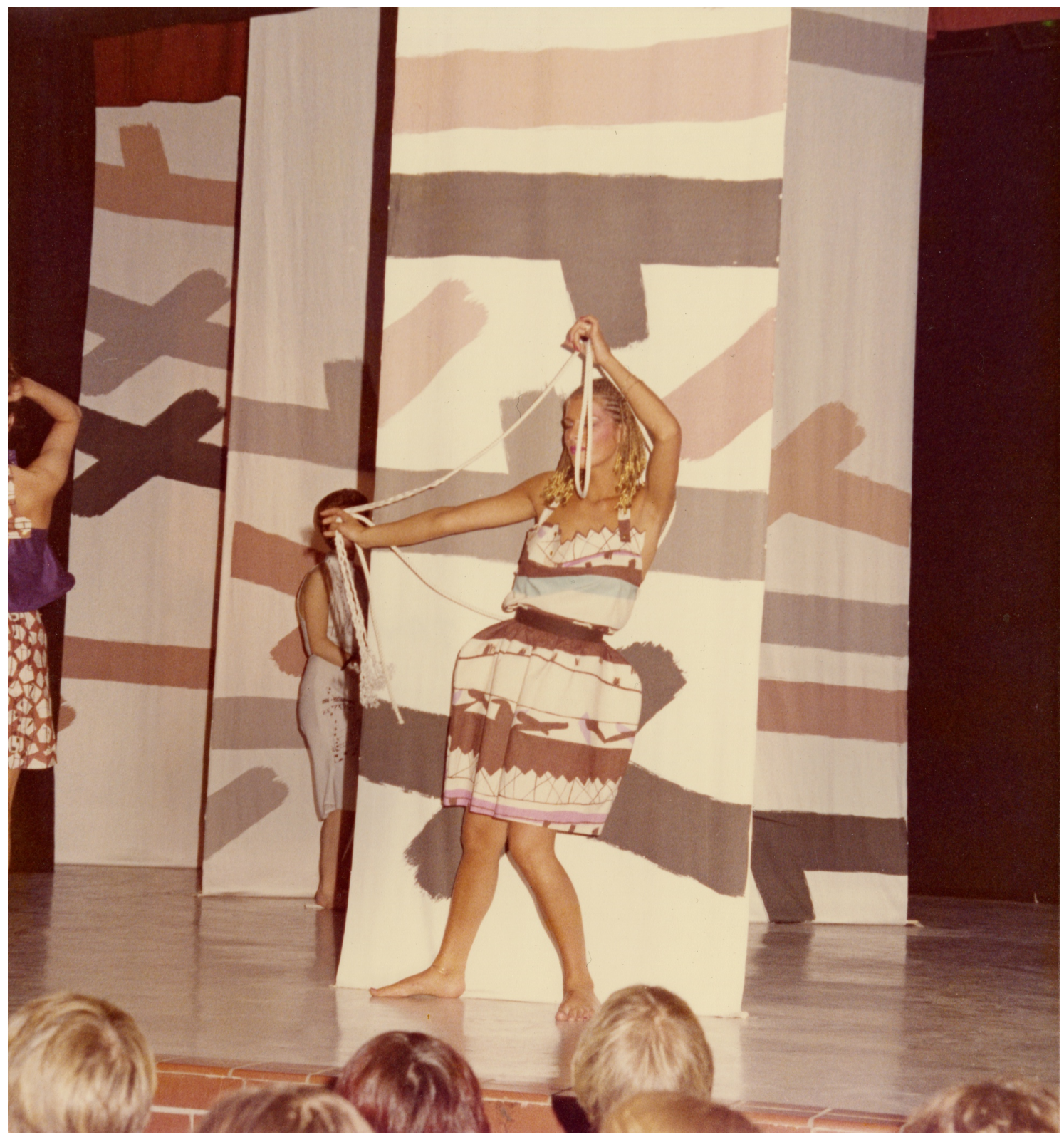

Figure 9. Models wearing Fraser Taylor's garments in front of backdrops by May Eatkin, GSA Fashion Show 1980. Courtesy of The Glasgow School of Art Archives \& Collections, Fraser Taylor and The Cloth Collection, DC089/1/3/1.

In 1982 GSA's Student Representative Council (SRC) “... regained complete production control..." of the fashion show (GSA 1989: 2) and throughout this era the event was held in GSA's Assembly Hall (in GSA's Assembly Building, home of the SRC). Fashion Show audio-visual recordings show a range of outfits from costumes to 
wearable garments. The costume emphasis is highlighted in the 1983 show which features a look reminiscent of a fluffy pink chicken (Brogan 1983). Another costume worthy of note is an extravagant replica of a 1760s ball gown, presented in the show and subsequently exhibited at "Young Blood", Barbican Centre, London (GSA 1982, 1984). Other costume-like garments communicated topical issues, for example, a dress made out of cigarette packets, worn by a model smoking (GSA 1986a). In 1985, screen printed garments were paraded down the catwalk to Free Nelson Mandela by The Specials (GSA 1985). A tutor recalls a mid-80s fashion show which included a handpainted coat featuring a map of Scotland highlighting American cruise missile production and centaurs decorated with four insignia of political power (Banerjee 2015). Fraser (1991: 38) suggests that 1980s GSA fashion shows “...became very theatrical and dramatic...”, relying “...heavily on the shock element rather than on clever design." However, the event provided students with opportunities to work outside of disciplinary boundaries and explore contemporary themes through dress and performance.

Fashion shows of this era also presented wearable garments, some of which were produced by students as part of the textiles curriculum. These included coats created for a competition with Harris Tweed (GSA 1986a) and a collection of kipper ties, the motif of which transferred to the show's poster (Figure 10). The 1983 show organizer highlighted the wider importance of the event: "We want to take the art school into the streets and to tell people that we do get jobs and we are worthwhile." (Brogan 1983: unknown) For this particular show, it took two fundraising dances to finance the catwalk, and another show took place outside of GSA, as a fundraiser to support those with disabilities (Brogan 1983). 


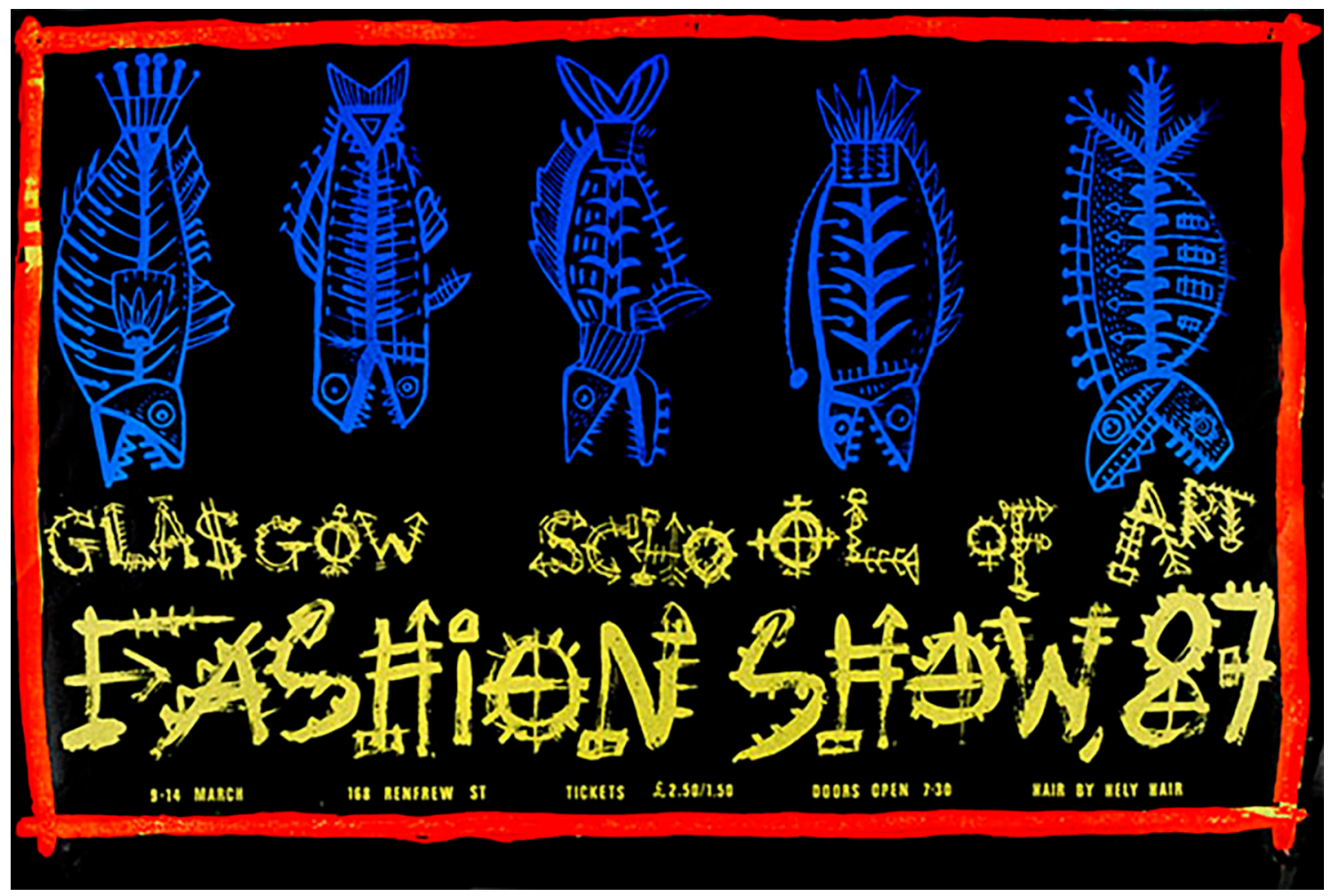

Figure 10. GSA Fashion Show poster 1987, designed by Paul Simmons and Alastair MacAuley. Courtesy of The Glasgow School of Art Archives \& Collections, GSAA/EPH/10/58.

During the 1980s, the fashion show was part of Activities Week, evident on a poster from 1986; for this show the Royal Scottish Academy of Music and Drama designed and constructed the set (GSA 1986b). Records relating to the 1989 show include programme, tickets, photographs and news cuttings, the majority of which were collected by Fraser (1991), as part of her dissertation research and role as fashion show producer for this year. The 1989 programme highlights the importance of sponsors to the event, as numerous companies and individuals provided in-kind and cash donations. The fashion show was organized by a student committee with the diversity of the show attributed to the involvement of students from a variety of disciplines across the School: "The students organise all aspects of the show, including the stage management, lighting and promotion. As the school does not have its own fashion department, the 
150 outfits on display have been designed by 80 students from various disciplines."

(Hutchinson 1989: unknown) Involvement is explicitly recognized by GSA's Director as potentially beneficial to future career aspirations:

"...the opportunity for all students in the School to take part in the annual event is unencumbered by the presence within the School of any dedicated fashion course. Through the opportunity that the Student Representative Council provides it has enabled many students in past years, and I have no doubt on this occasion, to consider eventual employment in one of the associated activities." (GSA 1989)

\section{The 1990s - Increasing Scale}

To date, minimal records have been located relating to the early 1990s GSA fashion shows. Newspapers include small features with little information except for photograph and brief description, for example: "The annual unconventional fashion gala...gets under way tomorrow night when 25 models will be taking part...” (The Sunday Times 1991: unknown). At this time, undergraduate courses existed in "Embroidered and Woven Textiles", and "Printed and Knitted Textiles"; course descriptions emphasize "learning by doing", reinforced by industry-based projects (GSA 1990: 25). Third-year Embroidered and Woven Textiles involved “...the application of ideas to real situations, by undertaking work for clients, through collaboration with industry, and by participation in selected competitions." (GSA 1990: 25) Connections between the different textile areas are also mentioned.

Under the Students Representative Council (SRC), Activities Week was usually organized by students and staff, but on occasion, it would be organized solely by students. In 1990-91, the fashion show is not mentioned as part of Activities Week, but 
the SRC highlights the event using the same text as in the 1980-82 prospectus, cited above. During the early 1990s, organisation of the show began three months before the event, with time "...used to contact and inform the press and to build a strong publicity campaign..." due to "...the heavy finances involved in such a show, an emphasis is strongly placed on finding potential sponsors" (Fraser 1991: 35). During the mid 1990s, the SRC viewed Activities Week and the fashion show as the Associations two major events. The show offered "...opportunities...for students to work collectively with the aim of developing and demonstrating their creative abilities in the areas of stage design, costume design, direction, lighting, music, choreography, modelling, etc." (GSA 1994: 11).

In 1994-95, GSA offered degrees in Embroidered \& Woven Textiles, run by White, and Printed \& Knitted Textiles, with Lindsay Taylor as Head. The Embroidered \& Woven Textiles course description mentions "Live projects with textile companies" (GSA 1994: 23) and third-year Printed \& Knitted Textiles expanded “...students’ analytical skills and ingenuity in the problem-solving aspects of designing for a particular purpose or market. Projects...involve working with industry and the local community." (GSA 1994: 25) The live projects and work with the local community mentioned could encompass the fashion show, however this is not explicitly stated. Photographs from the 1995 show capture a party-like atmosphere and the 1997 show features a mix of multiple material outfits paraded in front of plain fabric backdrops (Figure 11). The 1997/98 GSA prospectus ceases to mention the fashion show as SRC activity, at this time organization transferred to Printed \& Knitted Textiles, with involvement from Embroidered \& Woven Textiles. 


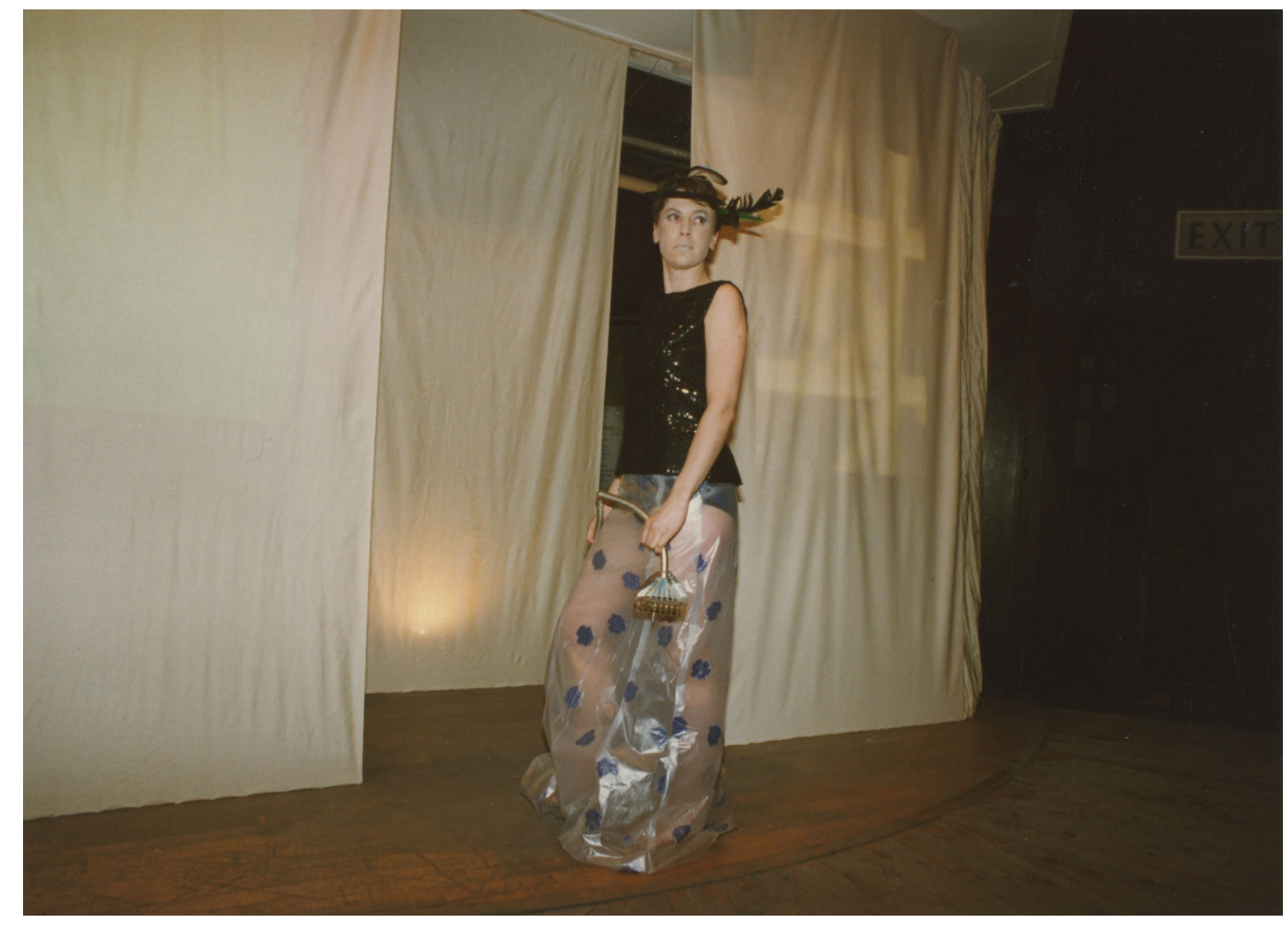

Figure 11. GSA student Kate Hollands modelling in GSA Fashion Show 1997.

Photograph by Sean Black. Courtesy of The Glasgow School of Art Department of Fashion \& Textiles.

During the late 1990s, there was a shift in the scale of the GSA fashion show, with large venues used around the city. The 1998 show, held at the Tramway, under the direction of lecturer Jimmy Stephen-Cran, included 40 collections “...paraded on a purpose-built catwalk...complemented with projections of ten video works by...interior designers." (The List 1998). This event signaled...

“...the start of a year-long process, intended to culminate in 'a major fashion event' as part of Glasgow's year as City of Architecture and Design 1999. And to prove that art students know how to party, the participants are inviting their audience back to the art school for a club night..." (The List 1998: unknown) 
In 1999 GSA's two textile departments were amalgamated into a single Department of Textiles, combining the four disciplines of embroidery, weave, print and knit (GSA 1999). The 1999 show, themed "Morphogenesis '99", took place at The Arches (Figure 12), billed as a “...multi-media extravaganza..." with “...a spectacular series of projection and light sequences...created by the Interior Design department...complimented by a specially designed score from NVA's Gus Ferguson." (James 1999: 26) For this year, the GSA prospectus mentions the fashion show under "GSA's role in the wider community":

"Don't think traditional catwalk. Don't think traditional anything. This dazzling collaboration between third-year Textile students and the Interior Design department has taken Glasgow by storm year after year. Staged at some of the city's most exciting arts spaces...the shows are a complete sell-out. But always there's a special performance just for schools - just to remind pupils that imagination never goes out of style." (GSA 1999: 11) 

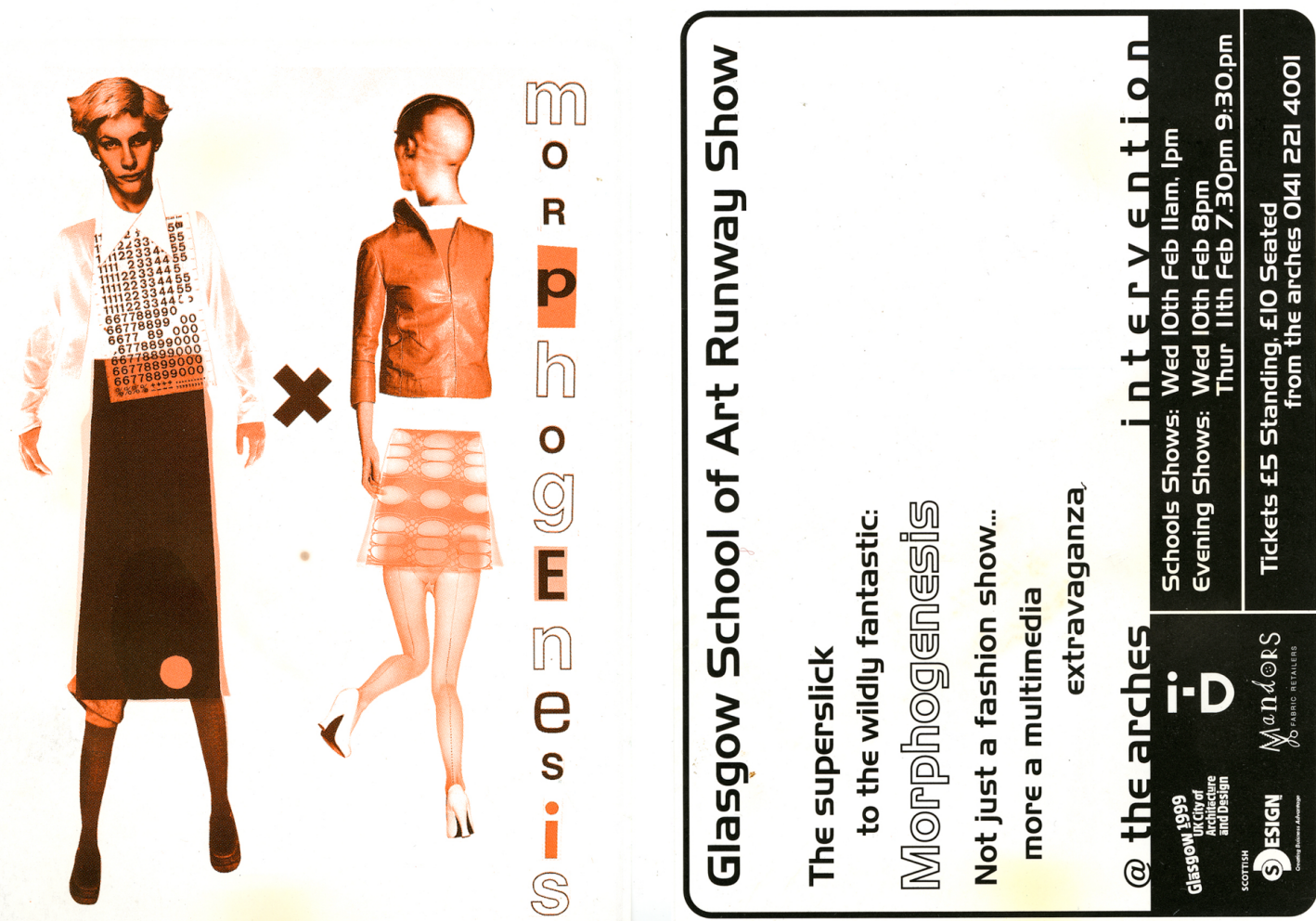

Figure 12. Fashion Show flyer 1999 (front and back). Courtesy of Private Collection of Mary-Ann Chatterton.

\section{The 2000s - New Millennium, New Technology}

Press exposure continued to increase with reports publicizing the show, presenting student looks and citing textile graduate successes. Head of Textiles, Taylor described the event as "... a showcase for talent...It's a fantastic launchpad for the designers of the future and a great way to show everyone just what an asset Glasgow has in its Art School." (Fotheringham 2001: unknown) At this time, textile students acquired fundamental skills in weave, print, knit and embroidery before specializing in either one or two of these disciplines (GSA 2000). For the fashion show, over a three-week period, students produced four to six garments, working with sourced materials and imaginative forms of garment construction (Dixon 2000). Third-year students continued to run the show, they explained: 
"We have to form committees... and organise everything from publicity to getting a venue and sponsors...it's a good trial run for the degree show and it also gives us the chance to work with models...it's a chance for our work to be subject to public scrutiny." (Dixon 2000: unknown)

In 2001, the Centre for Advanced Textiles (CAT), a digital textile printing facility was established at GSA. Taylor became Centre Director and Stephen-Cran, Head of Department for Textiles. The undergraduate textile design course changed so that students experienced weave, print, knit and embroidery, before specializing in one discipline at the end of second-year (GSA 2003). For third-year, textile-led garment creation for the fashion show was given increased time within the curriculum. For the 2002 event more than 90 students from GSA's textile design course participated:

"The interesting thing about this show is that these students are not doing a fashion course, so they don't know the rules, and are more likely to break them. And that's when true innovation happens...The work that will be shown at this year's event reflects trends in contemporary fashion and design...Fabric surface is now seen as being as important as shape, so textile designers are, at long last, enjoying the same public applause as fashion designers." (Fortheringham 2002: 17)

From this context the "advanced skills" taught postgraduate programme, Master of Design (MDes) Textiles as Fashion evolved, “...designed to meet the ambitions of textile graduates who wish to inspire to assert Fashion from the 'Textile-outwards' (as opposed to the 'Silhouette-inwards')" (GSA 2004a: 62). This new programme is 
mentioned in press publicizing the work of GSA's first practice-based Doctor of Philosophy (Ph.D.) graduate; the garments resulting from this $\mathrm{Ph} . \mathrm{D}$. project featured in the 2003 GSA fashion show, alongside the work of undergraduate students (McQuillan 2003).

In 2004, to make the fashion show profitable, the event returned to GSA's Students' Association (GSASA) building, the Assembly Hall (GSA 2004b), and the accompanying 'Boutique' was introduced as a pop-up shop for which third-year students created multiples of textile-based items to sell. Enhancement of the undergraduate textile design programme led to the organization of the fashion show forming the basis of a professional skills project within the third-year curriculum, with input from GSA's Careers Services. This initially involved four teaching staff working with groups of students, later changing to a single staff member as Fashion Show Coordinator, overseeing the different organizational teams. This new format attracted increased external sponsorship and the show included garments by second-year textile students and mini collections of 3-6 looks from third-year students (Figure 13). The 2005 project challenged students to “...find a conventional garment, something ordinary, and reinterpret it..." (Robertson 2005: 16). Reports from this show highlight increased emphasis on the organization of the event as a learning activity:

“...the fashion show's not just about showing...cutting-edge ideas - it also offers third-year students first-hand experience of the professional world. As well as nurturing each student's creative identity, the fashion show develops team skills and resourcefulness - necessary attributes for future careers." (Robertson 2005: 16) 


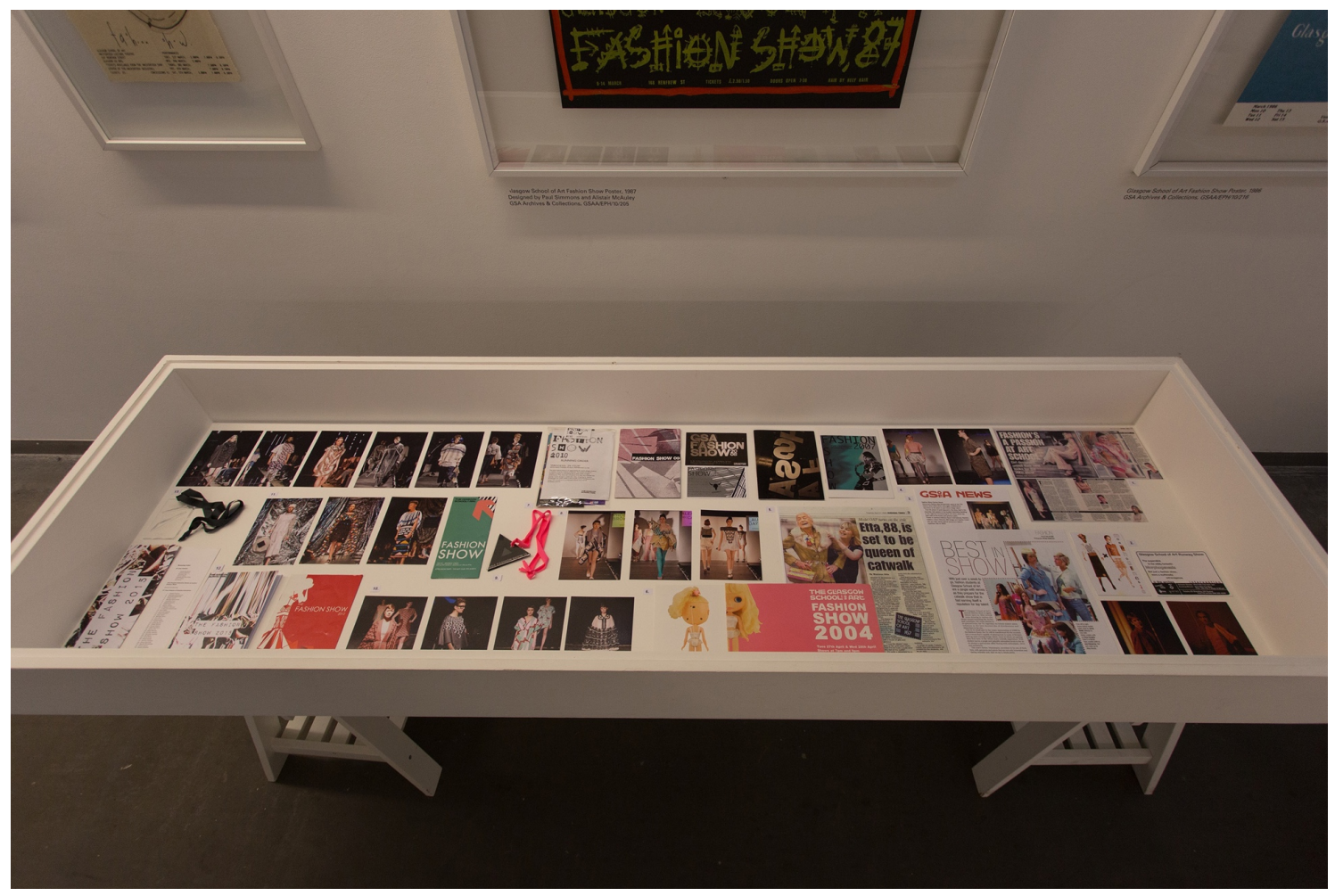

Figure 13. GSA Fashion Show $70^{\text {th }}$ Anniversary Exhibition vitrine displaying news cuttings, ephemera and photographs from 2001-2015. Photograph by Jack McCombe.

Later fashion shows of this era provided students with opportunities to work with external companies, organizations and visiting practitioners. For 2006, students collaborated with a film company, “...third-year textiles students were asked to use the film's script as a catalyst to create designs which are environmentally sustainable and resource-efficient...The role of these students is to challenge the sameness of massproduced globalised fashion and branding culture', (The Herald 2006: unknown). Upcycling was the focus of the 2007 show "Reject Rag - Reborn", for which “...Charity Cancer Research UK donated 450 bags of unsaleable clothes, linens and materials to the Art School for the students to rework and revive as they saw fit" (Ellis 2007: 18). In 2008, third-year students worked with visiting lecturer Julian Roberts to create three looks; “This year's Glasgow School of Art fashion show kicked off last 
night with a plethora of edgy experimental outfits made by third-year textiles students." (Evening Times 2008: unknown)

For the event, students have created blogs, websites, appeared on local television, compiled short films, and were part of a test recording for new technology by a music and film company (Popmorphic 2009) (figure 14). The rise of social media, vlogging, sites such as Flickr and YouTube has led to increased dissemination of the event through multi-media channels. Positive experiences gained by students of the professional world through involvement in the fashion show, and the fundraising purpose of the event, required to enable student participation in the graduate show, New Designers, is evident in the media (McMeekin 2009).

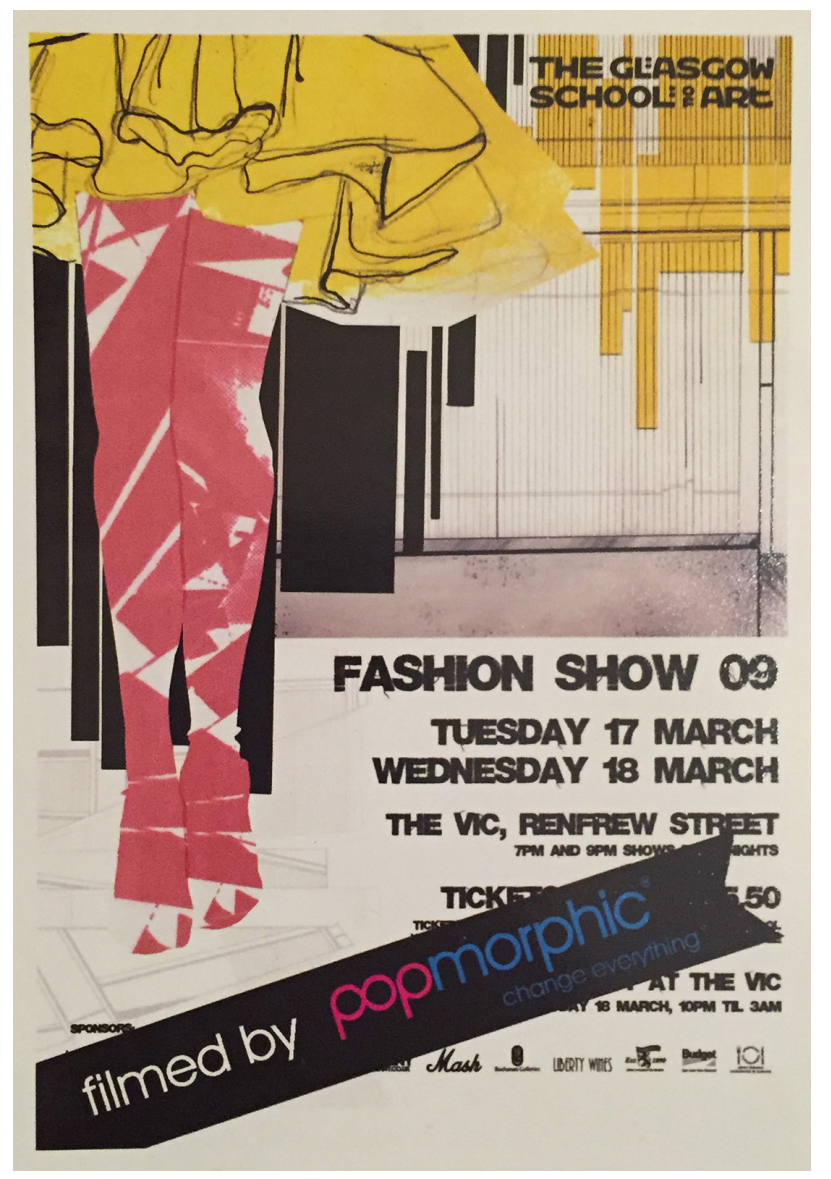

Figure 14. Fashion Show flyer 2009. Courtesy of The Glasgow School of Art Department of Fashion \& Textiles. 


\section{The 2010s - Textiles and Fashion}

From 2010-12, students exhibited work within the windows of a Glasgow shopping center as part of a new sponsorship deal and as promotional activity for the fashion show. In 2011, GSA began campus redevelopment and this provided the theme for the show (figure 15):

"Glasgow School of Art's Newbery Tower is one of the highest points in the city: a grim, grey beacon to 1970s architecture. Its scheduled demolition this summer is set to change the city's skyline dramatically, which is why for this year's annual fashion show (the last to take place in GSA's legendary Vic Bar, too) the textile students who have made the Newbery their home for over 30 years are paying tribute to the tower block in their capsule collections." (Innes 2011: unknown)

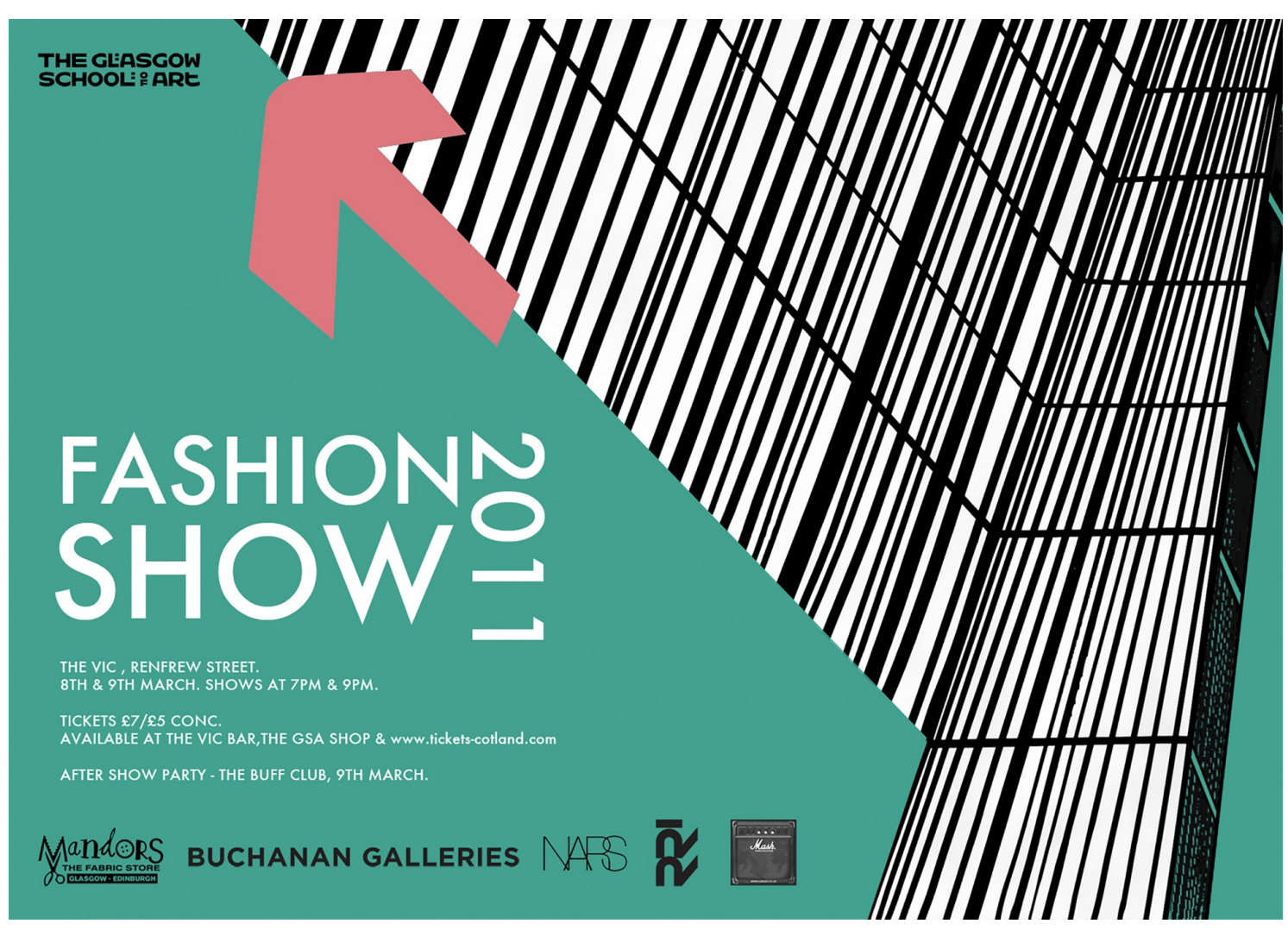

Figure 15. Fashion Show poster 2011. Courtesy of The Glasgow School of Art Archives \& Collections, GSAA/EPH/10/230. 
Fashion was introduced at undergraduate level, within the renamed Department of Fashion \& Textiles. Due to campus redevelopment, the 2012 show took place at SWG3. The 2013 show, held at The Arches, included work by second and third-year fashion, and third-year textiles. Second-year fashion students created two garments, one black and one white. Third-year fashion worked on a sponsored project with 'Androgyny' as a theme, to explore contemporary applications of Harris Tweed. Third-year textiles created garments for a centenary collaboration with the Royal Conservatoire of Scotland and the BBC Scottish Symphony Orchestra:

"The aim was to produce...designs for a ballet performance as well as the GSA Fashion Show. The students have used The Rite of Spring, a ballet and orchestral work written for the 1913 Ballet Russes company by Russian Composter Igor Stravinsky, as a starting point." (Fiddes 2013: 35)

GSA's new Reid Building opened in 2014, housing the Department of Fashion \& Textiles and the fashion show for this year took place in the redeveloped GSASA building, renamed The Art School. The theme of the show surrounded 'lace' and used GSA's A\&C to study historical examples as design inspiration. The 2015 show theme challenged students to consider the role fashion can play in the perpetuation of cultural stereotypes, explored issues of cultural appreciation (not appropriation), ancient cultural traditions (versus transient fashion) and non-western world dress traditions (Britt et al. 2017b). The 2016 show addressed gender neutrality from both design and organizational perspectives. For the seventieth-anniversary fashion show (22-23 March 2017) (Figure 16), students selected inspiration from a period between '1947-2017' and investigated either social or political changes; science and technology; music, fashion, 
film and television; art, literature and architecture. Some selected inspiration from GSA $\mathrm{A} \& \mathrm{C}$ and, in particular triggers from past fashion shows to develop their design ideas. For recent shows, collaboration with other GSA departments has varied from year to year, with third-year fashion and textiles working with students from Architecture for staging and set design, Communication Design for graphics and posters, and Interaction Design for projections and lighting displays.

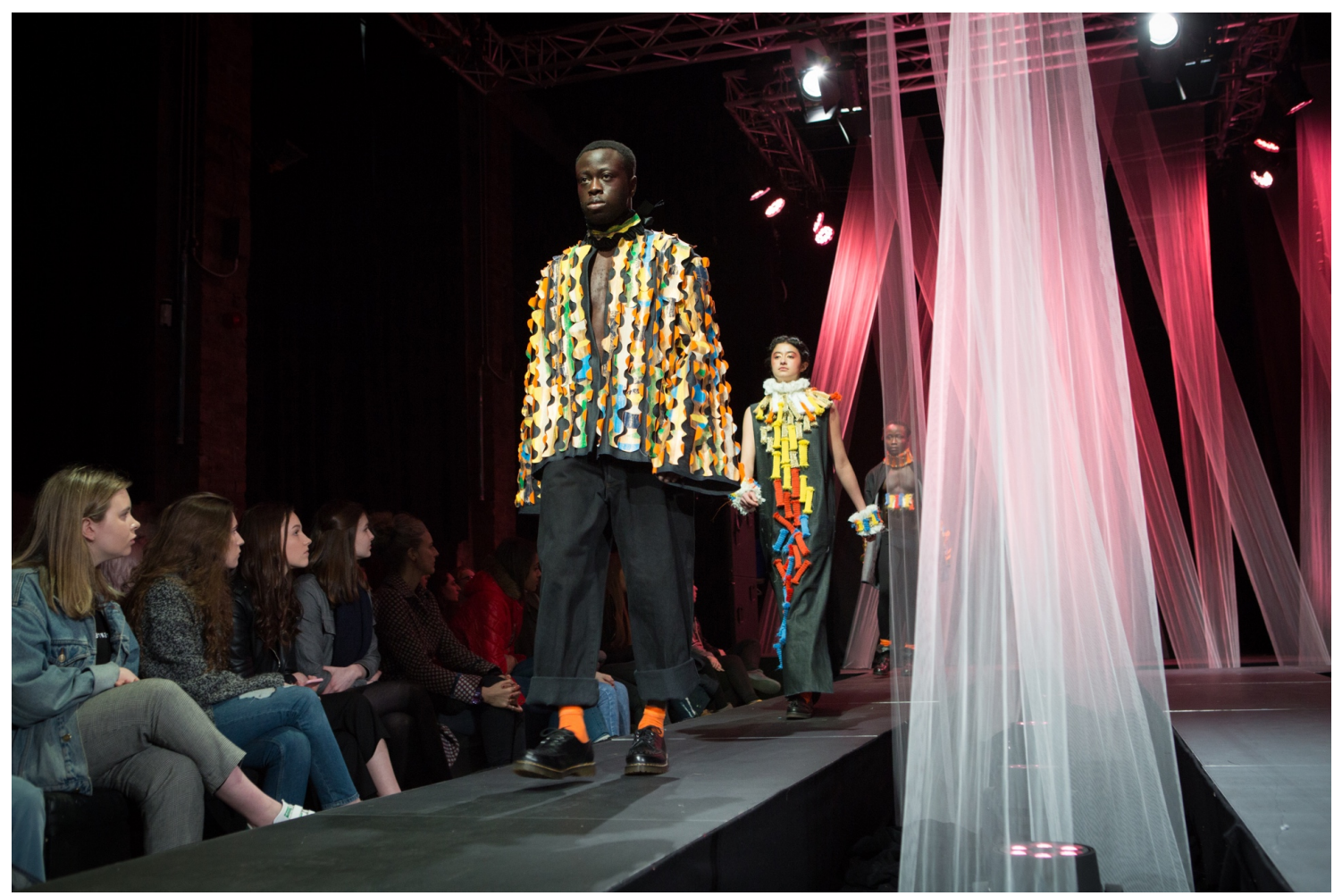

Figure 16. Models wearing garments by third-year student Joyce Tyson, GSA Fashion Show 2017. Photograph by Alan McAteer, McAteer Photograph. Glasgow School of Art Flickr - Fashion Show 2017.

The professional skills project relating to the organizational aspects of the GSA fashion show has been refined annually since the mid-2000s, working with GSA's Careers Services. Staff continually enhance the project to enable students to develop key transferable skills such as team working, team responsibility, problem solving, initiative, multitasking, budgeting, networking, communication and negotiation. 
Involvement in other tasks is also required including contacting schools and Further Education (FE) institutions, press and publicity, running the boutique, front of house, back stage and corporate hospitality. Students apply to and work in groups, either Sponsorship and Fundraising, Visual Identity and Marketing, Event Design or Show Production. As part of the project, students meet in their groups on a weekly basis, visit GSA A\&C for inspiration, attend employability themed workshops, utilize GSA Careers Services to enhance their curriculum vitae, work with external companies, organisations and various support departments at GSA, including Marketing, Development, Alumni Relations and Press. The project begins in October and continues until after the fashion show has taken place, usually in March of the following year, concluding with student group presentations to reflect upon and articulate professional skills learning, self and peer-evaluation. Shows tend to take place over two days, with three shows each day; daytime shows are targeted towards school pupils and FE students from Glasgow and surrounding areas. In addition to being an important employability learning experience for GSA students, the fashion shows, accompanying boutique (now a separate project within the curriculum) and after-show party are necessary fundraising activities to support student participation at London-based graduate shows, New Designers and Graduation Fashion Week, the following year. The fashion show as a third-year student project, prepares the cohort for working together to showcase their work at the end of their fourth-year.

\section{Conclusions}

This article has provided insight into a research project surrounding an Art School fashion show, for which educational institution archives and private collections have been utilized. The evolution of this specific fashion show, over a seventy-year period, has been discussed, in parallel with developments in textile and fashion design 
education at GSA. Charting the chronology of the event has highlighted change from student-initiated extra-curricular activity to higher education (HE) learning and teaching method. The importance of extra-curricular activities to GSA is particularly evident during the early years of the show and 1970-80s. Necessity to explicate the transferable and professional learning within HE creative education towards employability, has led to formalization of the fashion show into projects within the third-year (of the four-year) BA (Hons) Textile Design and BA (Hons) Fashion Design programmes at GSA. These projects are Design Collection (2001-), Professional Skills (2004-) and Boutique (2015). There is scope to further examine the fashion show from broader historical and contemporary pedagogical perspectives. Analysing wider existent research relevant to the project would also contextualize and benefit the project. Student and graduate feedback could be utilized to articulate further the employability skills and collaborative working processes developed through involvement in the fashion show. There is also potential to examine learning opportunities through student engagement with extracurricular activities in textiles and fashion.

It has been possible to gain insight into the fashion show as opportunity for crossdisciplinary collaboration. In particular, the shows of the 1980s organised by GSA's SRC included students from a multitude of disciplines across design, art and architecture. Opportunities were available for any student to be involved, whether in the organisation, staging, music, filming, photography, graphics, modelling or garment making. In recent years students from other disciplines have been involved with the fashion show, examples include working with Communication Design for poster design, Architecture for staging, Interaction Design for projections and model auditions are open to all. However, the event could be an opportunity for further collaboration across 
creative disciplines, which could enhance student learning. GSA's student union (GSA's SRC or GSASA) have supported the fashion show for the majority of years since the late 1940s, whether through providing the venue, support for stage build and lighting, organisation of the stand-alone event or as part of GSA's Activities Week. Reflecting on the evolution of the show, the relationship of the event to GSA's SRC and GSASA has been vital to its success and continuation. Further research could be carried out using the records and insights of those working at the GSA Students' Association.

Historically, we do not know if the event as a fundraising activity is unique to GSA. Therefore, it would be insightful to establish the role of fashion shows in textile and fashion education in HE. The early fashion shows were fundraisers for Charities Week and then for various other charities. In the 2000 s, the event became a student fundraiser to enable participation in graduate shows with increased support from external sponsors. If the show and its related events did not have to focus solely on fundraising for graduate shows, there could be further consideration of the benefits that the event could bring to the local community, surrounding area and perhaps once again to charity.

The research project at the center of this article provided an opportunity to locate and better understand fashion show related holdings within GSA's A\&C, insights gained by the authors will inform the development of future teaching resources and student projects. Although details relating to the themes of GSA fashion shows are not always evident, it is insightful to reflect on the emphasis on responsible design during certain periods. From material reuse and upcycling during the 1940s and 1950s, to garment de/re-construction and use of rags from a charity during the early 2000's. These influences continue to be embedded into GSA's textile design and fashion design curriculums. 
As part of the project, contacting alumni participants has resulted in items being accessioned to GSA's archives or the capture of materials through scanning and photography. Requesting alumni memories also provided insights, however more indepth data needs to be collected and captured, such as oral histories. There are still gaps in the holdings for specific time periods. School records, including annual reports from the 1980s onwards need to be viewed, and there are plans to catalog and make these accessible. News cuttings and magazine features have proved to be useful sources, however when these have been cut out and compiled into books and folders, essential publication information is missing, for example, newspaper and author names, page numbers and on occasion dates. Since the 2017 fashion show, a Heritage Lottery Fund Skills for the Future Trainee has been working with the audio-visual material from the 1980s. This has involved research to identify the models featured in the films and capturing other pertinent information to add to the A\&C catalog. Sessions held with GSA alumni and staff have been used for data collection, which has been added with short clips of the films to the online catalog.

More recently, digital technologies and online platforms have increased the variety of media generated surrounding the event, although there are issues with how to assimilate and store multi-media information to preserve it for future users. For the investigation, GSA printed prospectuses and annual reports have been valuable guides to School activities, programme content, teaching and learning methods. In recent years the annual prospectus has been replaced with a yearly general printed magazine and online programme guides. Online content needs to be stored as it is updated so it remains an 
accessible part of the institution's history, to ensure future generations have the opportunity to utilize archives for research, inspiration, learning and teaching.

\section{Acknowledgements}

The GSA seventieth-anniversary fashion show project has been possible due to funding and support received from the Incorporation of Skinners \& Glovers, GSA's School of Design, Archives \& Collections and Exhibitions Department. Special thanks go to those who responded to the GSA fashion show call for items and information; particularly to those who have lent and donated material to the archive.

\section{References}

Anon. 1977. "Students bring on the fashion clowns", Unknown, 1977. The Glasgow School of Art Archives \& Collections, GSAA/JAC/42.

Arthur, L. 2005. Textile Treasures at the Glasgow School of Art. London: A \& C Black Publishers Ltd.

Arthur, L. 2003. Robert Stewart Design, 1946-95. London: A \& C Black.

Arthur, L. 1994. The Unbroken Thread - A Century of Embroidery \& Weaving at Glasgow School of Art. Glasgow: Glasgow School of Art.

Arthur, L. 1989. Kathleen Whyte: Embroiderer. London: Batsford Ltd.

Banerjee, D. 2015. "Episode 05 - Some are big like pebbles and some are small like sand", New Wave: Materials, Methods and Media, Glasgow School of Art 1970-1986, Podcast. Available online at: http://www.gsaarchives.net/2015/11/episode-05-some-arebig-like-pebbles-and-some-are-small-like-sand/ [Accessed $10^{\text {th }}$ November 2017]. 
Britt, H., Waters, S. and Stephen-Cran, J. 2017a. The Glasgow School of Art Fashion Show, 1947-2017, Glasgow: Reid Corridor Gallery, Glasgow School of Art, $4^{\text {th }}-26^{\text {th }}$ March 2017.

Britt, H., Waters, S. and Stephen-Cran, J. 2017b. "The Glasgow School of Art Fashion Show, 1947-2017”, Art Libraries Journal, 42(3): 148-156.

Brogan, C. 1983. “Art among the pink chickens", Glasgow Herald, 25th April 1983. The Glasgow School of Art Archives \& Collections, GSAA/NEW/1/1.

Brown, P. 1961. “Art School Fashion Glasgow”, Glasgow Herald, 13 ${ }^{\text {th }}$ March 1961. The Glasgow School of Art Archives \& Collections, GSAA/NEW/1/1/9: 1960-1961. Daily Express. 1969. “Two views of fashion”, Daily Express, 12 ${ }^{\text {th }}$ March 1969. The Glasgow School of Art Archives \& Collections, GSAA/NEW/1/1.

Dixon, A. 2000. "Fashioning the future", Cog, 2000/1. The Glasgow School of Art Archives \& Collections, GSAA/NEW/1/1.

Ellis, M. 2007. "Rags to Riches", Evening Times, 12 $2^{\text {th }}$ March 2007. The Glasgow School of Art Department of Fashion \& Textiles.

Evening Citizen. 1949. "Fine Gowns from Old Army Blankets - or Muslin, or Calico", Evening Citizen, $3^{\text {rd }}$ January 1949. The Glasgow School of Art Archives \& Collections, GSAA/NEW/1/1/7: 1943-1952.

Evening Times. 2008. "Students turn on the style", Evening Times, $5^{\text {th }}$ March 2008. The Glasgow School of Art Department of Fashion \& Textiles.

Evening Times. 1953. "Fashion Show by Art Students", Evening Times, 15 ${ }^{\text {th }}$ January 
1953. The Glasgow School of Art Archives \& Collections, GSAA/NEW/1/1/8: 19521960.

Ferguson, H. 1995. Glasgow School of Art. Glasgow: The Foulis Press.

Fiddes, A. 2013. "Riot of Spring", The Skinny, $9^{\text {th }}$ March 2013. The Glasgow School of Art Department of Fashion \& Textiles.

Fotheringham, A. 2002. "Girl designers unveil their new looks for the 2002 show", Evening Times, $19^{\text {th }}$ April 2002. The Glasgow School of Art Department of Fashion \& Textiles.

Fotheringham, A. 2001. "Material Girls Go On Show", The Glasgow Evening Times, 7" February 2001. The Glasgow School of Art Archives \& Collections, GSAA/NEW/1/1.

Fraser, C. 1991. "A history and evaluation of the Glasgow School of Art Fashion Show". Unpublished Dissertation. The Glasgow School of Art Library, 085403.

Getty Images. Unknown. “Glasgow School of Art Fashion Show 1950”. Available online at: https://www.gettyimages.co.uk/photos/glasgow-school-of-art-fashion-show1950?phrase=glasgow\%20 school\%20of\%20art\%20fashion $\% 20$ show $\% 201950 \&$ sort=be st\#license [Accessed 10 $0^{\text {th }}$ November 2017].

Glasgow Caledonian University. 2018. 'The Glasgow and West of Scotland College of Domestic Science". Available online at: https://www.gcu.ac.uk/alumni/profile/thedoughschool/ [Accessed $14^{\text {th }}$ September 2018]. Glasgow Herald. 1975. "Fashion forecasts Glasgow School of Art”, Glasgow Herald, $17^{\text {th }}$ May 1975, pp. 9. The Glasgow School of Art Archives \& Collections, GSAA/NEW/1/1 
Glasgow School of Art. 2008. "The Glasgow School of Art". Available online at: https://www.flickr.com/photos/glasgowschoolart/ [Accessed $10^{\text {th }}$ November 2017].

Glasgow School of Art. 2004. Flow Magazine. Glasgow: Glasgow School of Art. Available online at: http://www.gsa.ac.uk/media/455295/flow_issue 4_a4.pdf [Accessed 12 $2^{\text {th }}$ November 2017].

Glasgow School of Art. 2004. Prospectus 2004/05. Glasgow: Glasgow School of Art. The Glasgow School of Art Archives \& Collections, GSAA/REG/1.

Glasgow School of Art. 2003. Prospectus 2003/04. Glasgow: Glasgow School of Art. The Glasgow School of Art Archives \& Collections, GSAA/REG/1.

Glasgow School of Art. 2000. Prospectus 2000/01. Glasgow: Glasgow School of Art. The Glasgow School of Art Archives \& Collections, GSAA/REG/1.

Glasgow School of Art. 1999. Prospectus 1999/2000. Glasgow: Glasgow School of Art. The Glasgow School of Art Archives \& Collections, GSAA/REG/1.

Glasgow School of Art. 1994. Prospectus 1994/95. Glasgow: Glasgow School of Art. The Glasgow School of Art Archives \& Collections, GSAA/REG/1.

Glasgow School of Art. 1990. Prospectus 1990/91. Glasgow: Glasgow School of Art. The Glasgow School of Art Archives \& Collections, GSAA/REG/1.

Glasgow School of Art. 1989. Fashion Show Programme '89. Glasgow: Glasgow School of Art. The Private Collection Carol Fraser.

Glasgow School of Art. 1986a. GSA Fashion Show film. Glasgow: Glasgow School of Art. The Glasgow School of Art Archives \& Collections, GSAA/AV/1/6. 
Glasgow School of Art. 1986b. Poster for the Glasgow School of Art activities week. Glasgow: Glasgow School of Art. The Glasgow School of Art Archives \& Collections, GSAA/EPH/10/217.

Glasgow School of Art. 1985. GSA Fashion Show film. Glasgow: Glasgow School of Art. The Glasgow School of Art Archives \& Collections, GSAA/AV/1/5.

Glasgow School of Art. 1984. Design from Glasgow School. Glasgow: Foulis Archive Press.

Glasgow School of Art. 1982. GSA Fashion Show film. Glasgow: Glasgow School of Art. The Glasgow School of Art Archives \& Collections, GSAA/AV/1/2.

Glasgow School of Art. 1980. Prospectus 1980/82. Glasgow: Glasgow School of Art. The Glasgow School of Art Archives \& Collections, GSAA/REG/1.

Glasgow School of Art. 1978a. Prospectus 1978/79. Glasgow: Glasgow School of Art. The Glasgow School of Art Archives \& Collections, GSAA/REG/1.

Glasgow School of Art. 1978b. Reports by the Governors and Accounts 1977-78.

Glasgow: Glasgow School of Art. The Glasgow School of Art Archives \& Collections, GSAA/GOV/1/10.

Glasgow School of Art. 1976. Reports by the Governors and Accounts 1975-76.

Glasgow: Glasgow School of Art. The Glasgow School of Art Archives \& Collections, GSAA/GOV/1/9.

Glasgow School of Art. 1975. Reports by the Governors and Accounts 1974-75.

Glasgow: Glasgow School of Art. The Glasgow School of Art Archives \& Collections, GSAA/GOV/1/9. 
Glasgow School of Art. 1974. Reports by the Governors and Accounts 1973-74.

Glasgow: Glasgow School of Art. The Glasgow School of Art Archives \& Collections, GSAA/GOV/1/9.

Glasgow School of Art. 1973. Reports by the Governors and Accounts 1972-73.

Glasgow: Glasgow School of Art. The Glasgow School of Art Archives \& Collections, GSAA/GOV/1/8.

Glasgow School of Art. 1972. Reports by the Governors and Accounts 1971-72.

Glasgow: Glasgow School of Art. The Glasgow School of Art Archives \& Collections, GSAA/GOV/1/8.

Glasgow School of Art. 1971a. Prospectus 1971/72. Glasgow: Glasgow School of Art. The Glasgow School of Art Archives \& Collections, GSAA/REG/1/6.

Glasgow School of Art. 1971b. Reports by the Governors and Accounts 1970-71.

Glasgow: Glasgow School of Art. The Glasgow School of Art Archives \& Collections, GSAA/GOV/1/8.

Glasgow School of Art. 1970. Prospectus 1970/71. Glasgow: Glasgow School of Art. The Glasgow School of Art Archives \& Collections, GSAA/REG/1/6.

Glasgow School of Art. 1969a. Reports by the Governors and Accounts 1968/69.

Glasgow: Glasgow School of Art. The Glasgow School of Art Archives \& Collections, GSAA/GOV/1/7.

Glasgow School of Art. 1969b. Prospectus 1969/70. Glasgow: Glasgow School of Art. The Glasgow School of Art Archives \& Collections, GSAA/REG/1/6.

Glasgow School of Art. 1967. Annual Report 1966/67. Glasgow: Glasgow School of 
Art. The Glasgow School of Art Archives \& Collections, GSAA/GOV/1/7.

Glasgow School of Art. 1965. Annual Report 1964/65. Glasgow: Glasgow School of Art. The Glasgow School of Art Archives \& Collections, GSAA/GOV/1/7.

Glasgow School of Art. 1964. Prospectus 1964/65. Glasgow: Glasgow School of Art. The Glasgow School of Art Archives \& Collections, GSAA/REG/1/5.

Glasgow School of Art. 1963. Fashion Show Poster. Glasgow: Glasgow School of Art. The Glasgow School of Art Archives \& Collections, GSAA/EPH/10.

Glasgow School of Art. 1960. Fashion Show - 20.05.1960. Glasgow: Glasgow School of Art. The Glasgow School of Art Archives \& Collections, GSAA/DIR.

Glasgow School of Art. 1955. GSA Fashion Show Programme 1955. Glasgow:

Glasgow School of Art. The Glasgow School of Art Archives \& Collections, GSAA/EPH/1/.

Glasgow School of Art. 1953. GSA Fashion Show Programme 1953. Glasgow:

Glasgow School of Art. The Glasgow School of Art Archives \& Collections, GSAA/EPH/1/.

Glasgow School of Art. 1947. Prospectus 1947/48. Glasgow: Glasgow School of Art. The Glasgow School of Art Archives \& Collections, GSAA/REG/1/4.

Hutchinson, D. 1989. "Fashion goes to the head", The Sunday Times Scotland, $5^{\text {th }}$ March 5 1989. The Glasgow School of Art Archives \& Collections, GSAA/NEW/1/1.

Innes, K. 2011. “The rising stars of Glasgow School of Art's textile department”, The List, $7^{\text {th }}$ March 2011. Available online at: https://www.list.co.uk/article/33078-the- 


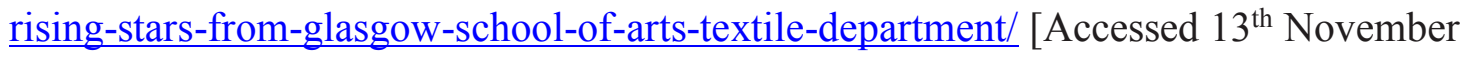
2017].

James, C. 1999. "Fashion show photograph", The Herald, $11^{\text {th }}$ February 1999. The Glasgow School of Art Archives \& Collections, GSAA/NEW/1/1.

McMeekin, E. 2009. "Why there's a new pattern emerging”, Evening Times, $16^{\text {th }}$ March 2009. The Glasgow School of Art Department of Fashion \& Textiles.

McQuillan, R. 2003. "All set to real what they sew”, The Herald, $16^{\text {th }}$ March 2003. The Glasgow School of Art Department of Fashion \& Textiles.

Moore, J. 1976. "Students of style set out to catch the eye", Glasgow Herald, $4^{\text {th }}$ March 1976. The Glasgow School of Art Archives \& Collections, GSAA/NEW/1/1.

Munro, M. 1964. "We're serious' - say the art school fashion designers", Evening Times, $12^{\text {th }}$ March 1964, pp. 6. The Glasgow School of Art Archives \& Collections, GSAA/NEW/1/1/10: 1961-1968.

Nicol, J. 1970. "Fashion from Art School”, Glasgow Herald, 13 $3^{\text {th }}$ May 131970. GSAA/NEW/1/1.

Petrie, L. 1952. "Student designers create fantasy fashions", Daily Record, $18^{\text {th }}$ January 1953: 8. Private Collection Betty Stewart.

Philpott, T. 1953. “Glasgow’s Gladdest Rag”, Picture Post, $7^{\text {th }}$ February 1953: 11-13. The Glasgow School of Art Archives \& Collections, GSAA/JAC/50.

Popmorphic. 2009. "Popmorphic Portfolio". Available online at: http://www.popmorphic.com/ [Accessed 13 $3^{\text {th }}$ November 2017]. 
Reid, J. 1965. “Students' Focus on Fashion - Practical Clothes of College Design”, Glasgow Herald, 13 ${ }^{\text {th }}$ March 1965. The Glasgow School of Art Archives \& Collections, GSAA/NEW/1/1/10: 1961-1968.

Robertson, L. 2005. “It's New Rags Week”, Evening Times, $4^{\text {th }}$ March 2005. The Glasgow School of Art Department of Fashion \& Textiles.

Schoeser, M. 2003. “Textiles”. In L. Arthur, Robert Stewart Design, 1946-95, pp. 6789. London: A \& C Black.

The Bulletin. 1960. "Art School Fashion Preview - Fantastic!”, The Bulletin, $11^{\text {th }}$ March 1960. The Glasgow School of Art Archives \& Collections, GSAA/NEW/1/1/8: $1952-1960$

The Bulletin. 1952. "For the Beach For Cocktails", The Bulletin, $18^{\text {th }}$ January 1952. The Glasgow School of Art Archives \& Collections, GSAA/NEW/1/1/7: 1943-1952.

The Daily Express. 1947. "Glamour? Even the Lights Blinked”, The Daily Express, 15 January 1947. The Glasgow School of Art Archives \& Collections, GSAA/NEW/1/1/7: $1943-1952$.

The Herald. 2006. "Film Fashion", The Herald, 15 ${ }^{\text {th }}$ March 2006. The Glasgow School of Art Department of Fashion \& Textiles.

The Herald. 1948. "Fashion Spotlight", The Herald, $21^{\text {st }}$ January 1948. The Glasgow School of Art Department of Fashion \& Textiles. The Glasgow School of Art Archives \& Collections, GSAA/NEW/1/1/7: 1943-1952.

The List. 1998. "Morphogenesis", The List, $23^{\text {rd }}$ January $-5^{\text {th }}$ February 1998. Private Collection, Mary-Ann Chatterton. 
The Sunday Times. 1991. "Putting on the style", The Sunday Times Scotland, 24 ${ }^{\text {th }}$ March 1991. The Glasgow School of Art Archives \& Collections, GSAA/NEW/1/1.

Young, B. 1968. "Student from Lagos directs Art School fashion show”, Glasgow Herald, $14^{\text {th }}$ March 1968. The Glasgow School of Art Archives \& Collections, GSAA/NEW/1/1/10: 1961-1968. 